\title{
Amphiphilic Nanocarrier Systems for Curcumin Delivery in Neurodegenerative Disorders
}

\author{
Miora Rakotoarisoa and Angelina Angelova *it \\ Institut Galien Paris-Sud CNRS UMR 8612, LabEx LERMIT, Univ Paris-Sud, Univ Paris-Saclay, \\ F-92296 Châtenay-Malabry, France; miora.rakotoarisoa@u-psud.fr \\ * Correspondence: angelina.angelova@u-psud.fr
}

Received: 30 October 2018; Accepted: 20 November 2018; Published: 23 November 2018

\begin{abstract}
Neurodegenerative diseases have become a major challenge for public health because of their incurable status. Soft nanotechnology provides potential for slowing down the progression of neurodegenerative disorders by using innovative formulations of neuroprotective antioxidants like curcumin, resveratrol, vitamin E, rosmarinic acid, 7,8-dihydroxyflavone, coenzyme Q10, and fish oil. Curcumin is a natural, liposoluble compound, which is of considerable interest for nanomedicine development in combination therapies. The neuroprotective effects of combination treatments can involve restorative mechanisms against oxidative stress, mitochondrial dysfunction, inflammation, and protein aggregation. Despite the anti-amyloid and anti-tau potential of curcumin and its neurogenesis-stimulating properties, the utilization of this antioxidant as a drug in neuroregenerative therapies has huge limitations due to its poor water solubility, physico-chemical instability, and low oral bioavailability. We highlight the developments of soft lipid- and polymer-based delivery carriers of curcumin, which help improve the drug solubility and stability. We specifically focus on amphiphilic liquid crystalline nanocarriers (cubosome, hexosome, spongosome, and liposome particles) for the encapsulation of curcumin with the purpose of halting the progressive neuronal loss in Alzheimer's, Parkinson's, and Huntington's diseases and amyotrophic lateral sclerosis (ALS).
\end{abstract}

Keywords: curcumin; lipid nanoparticles; liquid crystalline carriers; nanomedicines; neuroprotection; antioxidant

\section{Introduction}

Neurodegenerative diseases (Alzheimer's disease (AD), Parkinson's disease (PD), Huntington disease (HD), and amyotrophic lateral sclerosis (ALS)) are disabling chronic disorders characterized by the progressive loss of neurons in different areas of the central nervous system. Neuronal cell death leads to cognitive, behavioral, sensory, and motor dysfunctions [1-13]. Currently, age-related neuronal diseases have higher incidences because of increasing life expectancies. Neurodegenerative disorders are caused by multiple factors, such as the accumulation of misfolded proteins, the depletion of endogenous antioxidant enzyme activity, mitochondrial dysfunction, and the deficiency of neurotrophin brain-derived neurotrophic factor (BDNF), neuro-inflammation, as well as various genetic mutations [14-30].

In recent years, several studies have shown that curcumin is a safe natural compound which may prevent the deleterious effects of risk factors causing brain damage as well as slowing down the progressive neuronal loss via different pathways [26-50]. However, clinical studies performed with $\mathrm{AD}$ patients with various degrees of progression have reported poor results on the AD symptoms following curcumin treatment [51-54]. This did not allow firm conclusions about the therapeutic or neuroprotective potential of curcumin to be drawn. The obstacles for curcumin utilization as a drug originate from its limited water solubility, poor physicochemical stability, high-grade metabolism, 
and low plasma concentrations [36,53-55]. The development of nanoparticulate delivery systems for curcumin has attracted scientific interest in order to improve its bioavailability and stability as a drug compound [56-65]. Curcumin administration to neurodegenerative disease models by nanoparticles has been realized using liposomes, solid lipid nanoparticles, and polymeric particles. Delivery by other carriers such as amphiphilic proteins, e.g., casein, is also possible, but has not been examined as a means of transporting curcumin across the BBB towards neuro-regeneration.

In this review, we briefly summarize the in vitro and the in vivo evaluations of curcumin, which are linked to multiple risk factors and the multi-target mechanisms of neurodegenerative diseases, and discuss the reported clinical investigations of varying efficacy in humans. Then, we highlight the variety of amphiphilic curcumin-loaded nanocarriers including liposomes, liquid crystalline nanoparticles (cubosomes, hexosomes, and spongosomes), solid lipid nanoparticles, micelles, and polymeric nanoparticles as potential nanomedicine formulations in regeneration therapies of the major neurological disorders.

\section{Risk Factors for Neurodegenerative Disorders}

Alzheimer's disease (AD) is the most common cause of dementia. It currently affects about $10 \%$ of the world's population over 60-65 years of age, and about 50\% over 85 years of age. More than 30 million people may expect to be affected by AD during the next 20 years due to the increasing lifespan of the world population [1,2]. Major pathological features of AD include the accumulation of extracellular amyloid plaques and fibrils, intracellular neurofibrillary tangles, and disruption of the cholinergic transmission, including reduced acetylcholine levels in the basal forebrain (Table 1). The most common symptom is the short-term memory loss, i.e., difficulty in remembering recent events [2-5]. Other symptoms include disorientation, mood, language, and behavioral issues, and loss of motivation, depending on the progression of the disease. The treatments of AD have employed acetylcholinesterase inhibitors (tacrine, rivastigmine, galantamine, and donepezil) to overcome the decrease of the ACh levels as a result of the death of cholinergic neurons. The NMDA receptor antagonist (memantine) acts by inhibiting the overstimulation by glutamate, which can cause cell death. Atypical antipsychotics have modest efficacy in reducing the aggression and psychosis of AD patients. These medications provide little benefit, and provoke various adverse effects [6,7].

The second most common disorder, Parkinson's disease (PD), affects more than 1\% of the population over 60 years of age and $5 \%$ over 85 . PD is characterized by progressive impairments in locomotive ability such as tremor, rigidity, and bradykinesia. These symptoms are attributed to the loss of dopaminergic neurons in the substantia nigra and the formation of Lewy bodies in the brain [8,9]. Treatments are symptomatic and aim at boosting the depleted levels of dopamine (Table 1). The most used drug is levodopa. Dopamine agonists are used when the treatment by levodopa becomes less efficient. The inhibitors of MAO-B and COMT (safinamide, selegiline, rasagiline, and tolcapone) are used to inhibit the activity of the enzymes which degrade dopamine. These medications become less effective as the neurons are continuously lost during disease progression. At the same time, they produce complications marked by the involuntary movements of the patients $[8,9]$.

Huntington disease (HD) is a rare disease which affects about $1 / 10,000$ people (usually between 30 to 50 years of age) in the United States and 1/18,000 people in Europe. It is a poly-glutamine (PolyQ) autosomal genetic disorder characterized by impairments of cognitive, psychiatric, and motor functions [10]. The hallmark of the HD pathology is the abnormal accumulation of misfolded mutated huntingtin protein (mHTT) as intracellular aggregates. They cause selective neuronal loss, primarily in the cortex and in the medium spiny neurons of striatum. Symptoms develop from a general lack of coordination to apparent uncoordinated, jerky body movements [11]. The physical abilities of the patients gradually worsen until coordinated movement becomes difficult. There is no effective cure available to HD (Table 1). The only approved medication, tetrabenazine, and other tested drugs (neuroleptics and antipsychotics) help to reduce chorea and psychiatric symptoms. 
Amyotrophic lateral sclerosis (ALS) is a severe debilitating disease caused by motors neurons degeneration in the brain and the spinal cord. It is generally characterized by progressive paralysis starting at the limbs and ultimately leading to death caused by respiratory failure within 3 to 5 years after the onset of the symptoms. There is no cure for ALS (Table 1). The approved medication, riluzole, may extend life by just a few months $[12,13]$.

The pathological characteristics, genetic factors, clinical symptoms, and actual medications of these diseases are summarized in Table 1. It should be emphasized that the existing therapeutic approaches do not exert disease-modifying effects on the neurodegeneration. The associated economic and societal challenges lead to a growing public health burden.

Table 1. Pathological characteristics, genetic factors and clinical symptoms of Alzheimer's disease (AD), Parkinson's disease (PD), Huntington's disease (HD), and amyotrophic lateral sclerosis (ALS) [1-30].

\begin{tabular}{|c|c|c|c|c|}
\hline Diseases & Characteristics & Genetics factors & Symptoms & Actual treatments \\
\hline $\mathrm{AD}$ & $\begin{array}{l}\text { Senile plaques from } \\
\text { extracellular amyloid-A } \beta \\
\text { accumulation, } \\
\text { Intracellular neurofibrillary } \\
\text { tangles, Tau protein } \\
\text { aggregation, Irreversible } \\
\text { neuronal loss, Brain atrophy }\end{array}$ & $\begin{array}{l}\text { Inherited form }(70 \% \text { of } \\
\text { patients): mutations of APP, } \\
\text { PSEN1 or PSEN2. } \\
\text { Sporadic form }(30 \%) \text { : } \\
\text { presence of ApoE4 allele in } \\
\text { the ApoE gene }\end{array}$ & $\begin{array}{l}\text { Progressive } \\
\text { memory loss, } \\
\text { Decision } \\
\text { judgement loss, } \\
\text { Autonomy loss }\end{array}$ & $\begin{array}{l}\text { Anticholinergics } \\
\text { (tacrine, rivastigmine, } \\
\text { galantamine and } \\
\text { donepezil), } \\
\text { Memantine, } \\
\text { Antipsychotics, } \\
\text { NSAIDs }\end{array}$ \\
\hline PD & $\begin{array}{l}\alpha \text {-Synucleinopathy, } \\
\text { Presence of Lewy bodies, } \\
\text { Degeneration of } \\
\text { dopaminergic neurons in the } \\
\text { substance nigra of the brain, } \\
\text { Dopamine deficiency }\end{array}$ & $\begin{array}{l}\text { Gene mutations: } \\
\alpha \text {-synuclein SNCA, Parkin } \\
\text { PRKN, PARK7, PINK1, } \\
\text { LRRK2, GBA, DJ-1, VPS35, } \\
\text { EIF4G1, DNAJC13 and } \\
\text { CHCHD2 }\end{array}$ & $\begin{array}{l}\text { Hypokinesia, } \\
\text { Bradykinesia, } \\
\text { Rigidity, } \\
\text { Postural instability, } \\
\text { Neuropsychiatric } \\
\text { disturbances }\end{array}$ & $\begin{array}{l}\text { Levodopa, } \\
\text { Dopamine agonists, } \\
\text { MAO-B inhibitors, } \\
\text { COMT inhibitors, } \\
\text { Anticholinergics }\end{array}$ \\
\hline HD & $\begin{array}{l}\text { Accumulation of mutant } \\
\text { Huntingtin protein in the } \\
\text { brain }\end{array}$ & $\begin{array}{l}\text { Expansion of CAG } \\
\text { trinucleotide in Huntingtin } \\
\text { gene (HTT) }\end{array}$ & $\begin{array}{l}\text { Chorea, } \\
\text { Cognitive and } \\
\text { neuropsychiatric } \\
\text { disorders }\end{array}$ & $\begin{array}{l}\text { Tetrabenazine, } \\
\text { Neuroleptics, } \\
\text { Antipsychotics }\end{array}$ \\
\hline ALS & $\begin{array}{l}\text { Progressive degeneration of } \\
\text { motor neurons }\end{array}$ & $\begin{array}{l}\text { Sporadic form: } 90 \% \text { of } \\
\text { patients } \\
\text { Inherited form: } 10 \% \\
\text { Mutations of SOD1, } \\
\text { TARDBP, FUS, UBQLN2, } \\
\text { OPTN, and C9ORF72 genes }\end{array}$ & $\begin{array}{l}\text { Spasms, } \\
\text { Muscle atrophy, } \\
\text { Squelettal muscle } \\
\text { paralysis, } \\
\text { Cognitive or } \\
\text { behavioral } \\
\text { dysfunction }\end{array}$ & Riluzole \\
\hline
\end{tabular}

Although the etiology and the pathological mechanism of the neurodegenerative diseases are not completely understood, it has been established that the progressive loss of neurons results from the combination of multiple factors (Figure 1). First, genetic factors are involved in the appearance of misfolded amyloid-A $\beta$ protein and other misfolded mutant forms like hyperphosphorylated Tau (p-Tau) and Huntingtin proteins [3-5,10,14]. All these mutated proteins aggregate and form deposits. The resulting aggregates can be toxic, and can affect the intracellular organelles such as mitochondria $[14,21,25,27]$. The disruption of the mitochondrial membrane causes neuronal cell death $[25,27]$. 

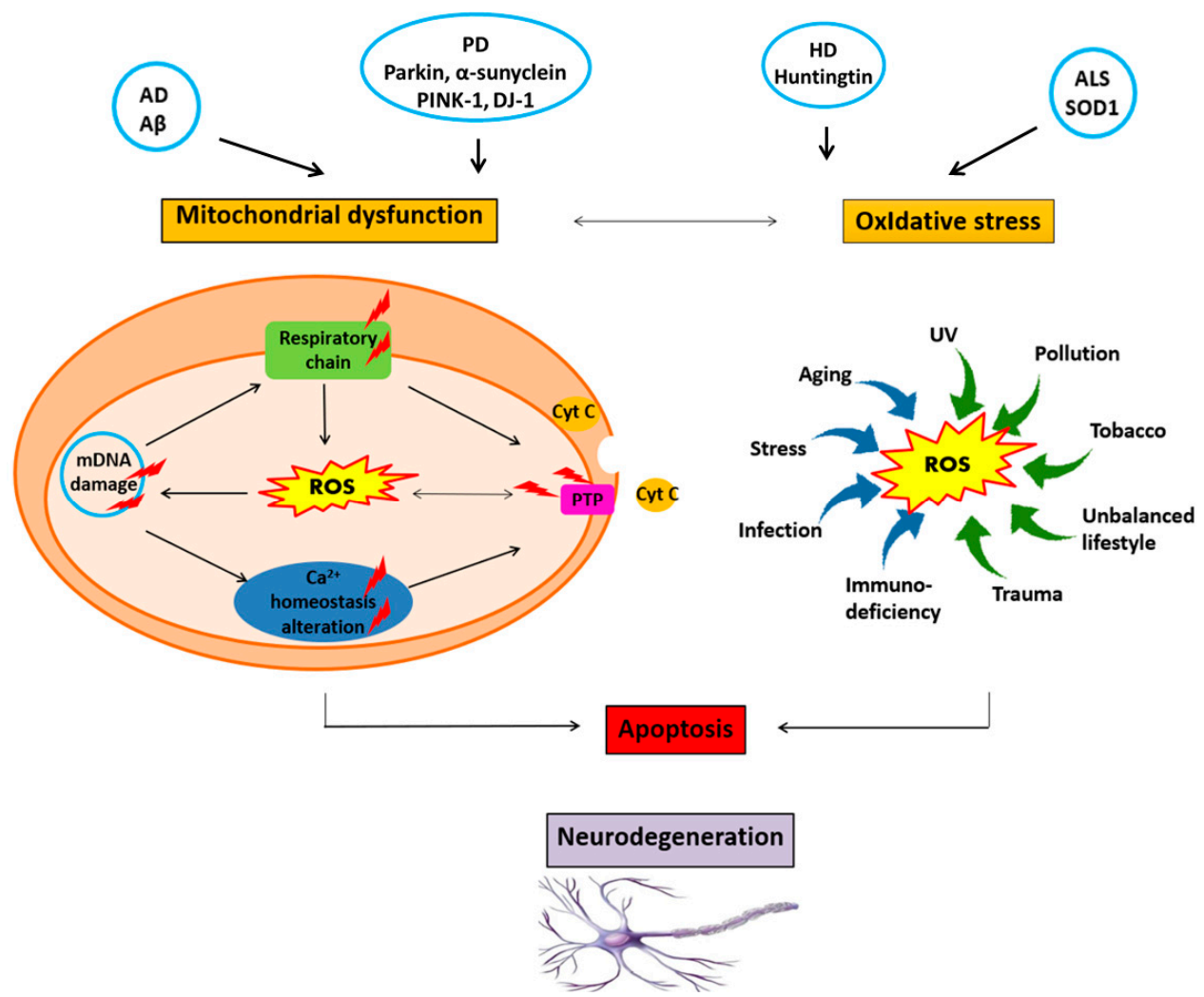

Figure 1. Neurodegeneration is triggered and boosted by a vicious circle involving neurotoxic protein accumulation, oxidative stress, mitochondrial damage, DNA damage, and impairment of the calcium $\left(\mathrm{Ca}^{2+}\right)$ homeostasis, neurotrophin deficiency, neuroinflammation, genetic, and environmental factors.

Second, neurotrophic factors deficiency has been reported in the severe neurodegenerative disorders [11,13,29-33]. Neurotrophins regulate the neuronal survival, differentiation, growth, and regeneration, as well as the synaptic plasticity. Studies have shown that the levels of brain derived neurotrophic factor (BDNF) and its tropomyosin kinase $B(\operatorname{TrkB})$ receptor are decreased in the hippocampus and the cerebral cortex at the beginning of the Alzheimer's disease [11]. In addition, the administration of BDNF mimetics into transgenic mouse models of AD has enhanced learning and memory capacities [31].

Third, oxidative stress is the most common feature of neurodegenerative diseases [15-20]. Reactive Oxygen Species (ROS) such as superoxide anions, hydroxyl radicals, and hydrogen peroxide $\left(\mathrm{H}_{2} \mathrm{O}_{2}\right)$ are produced by the mitochondrial transport chain, the endoplasmic reticulum, the Krebs cycle, and the plasma membrane involving the superoxide-generating NADPH oxidase (NOX) macromolecular complex [17]. Oxidative stress occurs under environmental factors and when the generation of ROS exceeds the natural antioxidant defenses of the cell (promoted by superoxide dismutase, catalase, glutathione peroxidase, carotenoids, and vitamins E or C) [15-20]. ROS accumulation attacks proteins, nucleic acids, and membrane lipids, and thus, causes impairments of the neuronal cell functions and integrity [18-20]. Mitochondrial lesions are also mediated by ROS. This leads to the alteration of the neuronal cell bioenergetics, the disruption of the calcium $\left(\mathrm{Ca}^{2+}\right)$ homeostasis, or the activation of the mitochondrial permeability transition pore (mPTP). Thus, a vicious cycle is formed (Figure 1), which amplifies the cellular dysfunction and triggers neurodegeneration [17-26].

Fourth, neuro-inflammation is a crucial factor that favors neurodegenerative disease development. Several inflammatory markers (such as chemokines, cytokines, or proteins in the acute phase) are upregulated and cause inflammation. In fact, elevated levels of the inflammatory markers have been found during the progression of the neurodegenerative diseases $[27,28]$. 


\section{Curcumin Potential for Neuroprotection against Neurodegenerative Diseases}

Curcumin is a hydrophobic polyphenolic substance (Figure 2) produced in the root of the plant Curcuma Longa L. This antioxidant compound is extensively marketed worldwide as a nutraceutical in various preparations, because it has a very safe nutraceutical profile with low side effects. Curcumin has been reported to be well tolerated at doses up to $8 \mathrm{~g}$ per day over short periods in humans [32]. Research on the pharmacological activities of curcumin has attracted strong attention in relation to its multiple actions of therapeutic interest, e.g., the anti-inflammatory, antioxidant, antiviral, antibacterial, antifungal, and antitumor activities. These activities appear to be dose-dependent [33].

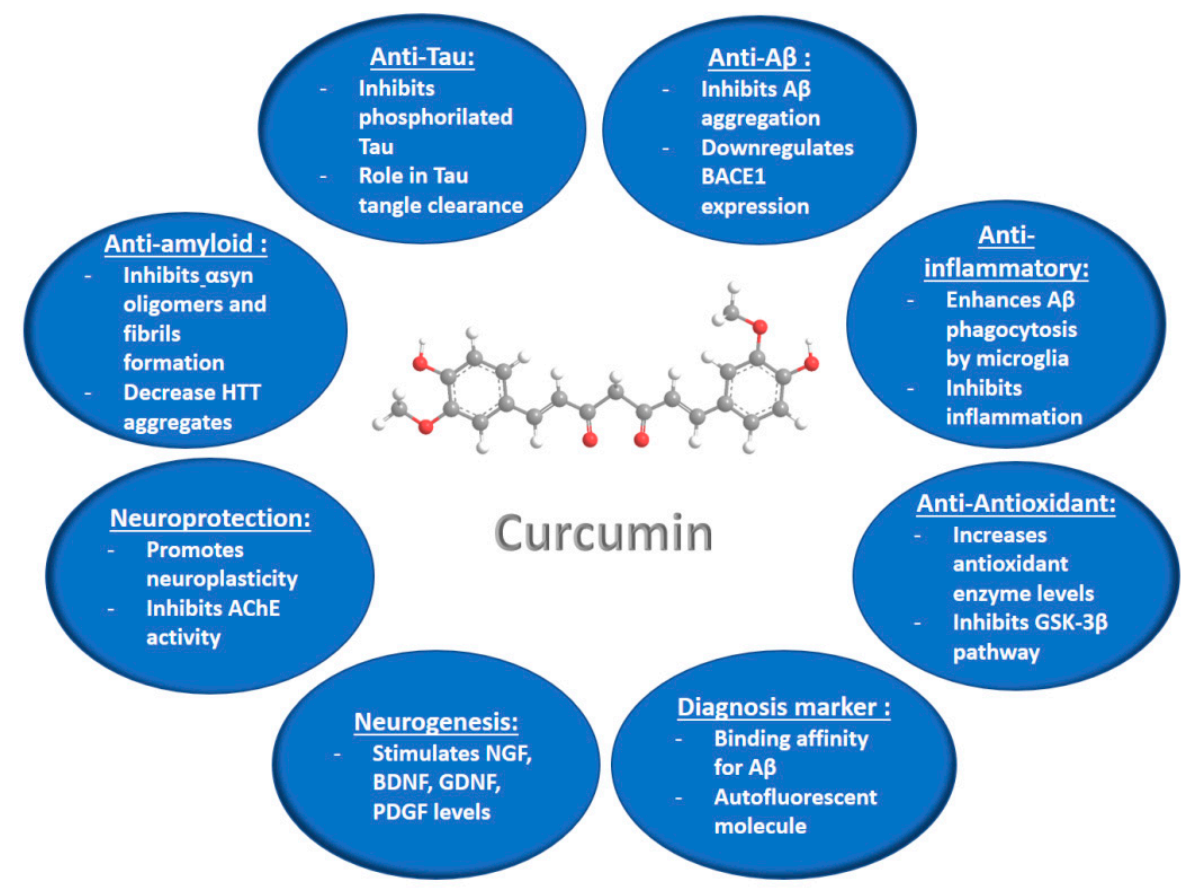

Figure 2. Summary of the curcumin activities and suggested mechanisms of action, which can be exploited for treatment of neurodegenerative diseases (according to information from ref. [36]).

\subsection{In Vitro and In Vivo Studies of Curcumin Properties in Neurodegenerative Disease Models}

The neuroprotective potential of curcumin (Figure 2) and its antioxidant, anti-inflammatory, and amyloid $A \beta$ binding properties have been highlighted in in vitro and in vivo investigations of different neurodegenerative disease models [33-42]. Curcumin has been found to increase the levels of glutathione (GSH) and malondialdehyde (MDA), as well as the antioxidant enzyme [superoxide dismutase (SOD), glutathione peroxidase (GPx), glutathione reductase (GR), and catalase (CAT)] activities in the rat brain, thus preventing the stress-induced oxidative damage of brain [37,39]. The anti-inflammatory properties of curcumin have been characterized by the inhibition of the inflammatory chemokines, by increased levels of the anti-inflammatory cytokines, and by enhanced expression levels of induced nitric oxide synthase (iNOS) and the transcription factor NF-Kb [39]. Curcumin has been shown to prevent the fibrillation of $\alpha$-synuclein at the earliest stage of the aggregation process, as well as the fibrillation of the globular protein hen egg-white lysozyme (HEWL) [40]. Both proteins are known to form amyloid-like fibrils. These results have suggested that curcumin might be a potential therapeutic agent for preventing protein aggregation in Alzheimer's, and Parkinson's diseases [40]. Recent in vitro and in vivo investigations of curcumin's activities in neurodegenerative disease models [41-50] are summarized in Table 2. 
Table 2. Recently reported curcumin (CU) activities in in vitro and in vivo models of neurodegenerative diseases [41-50].

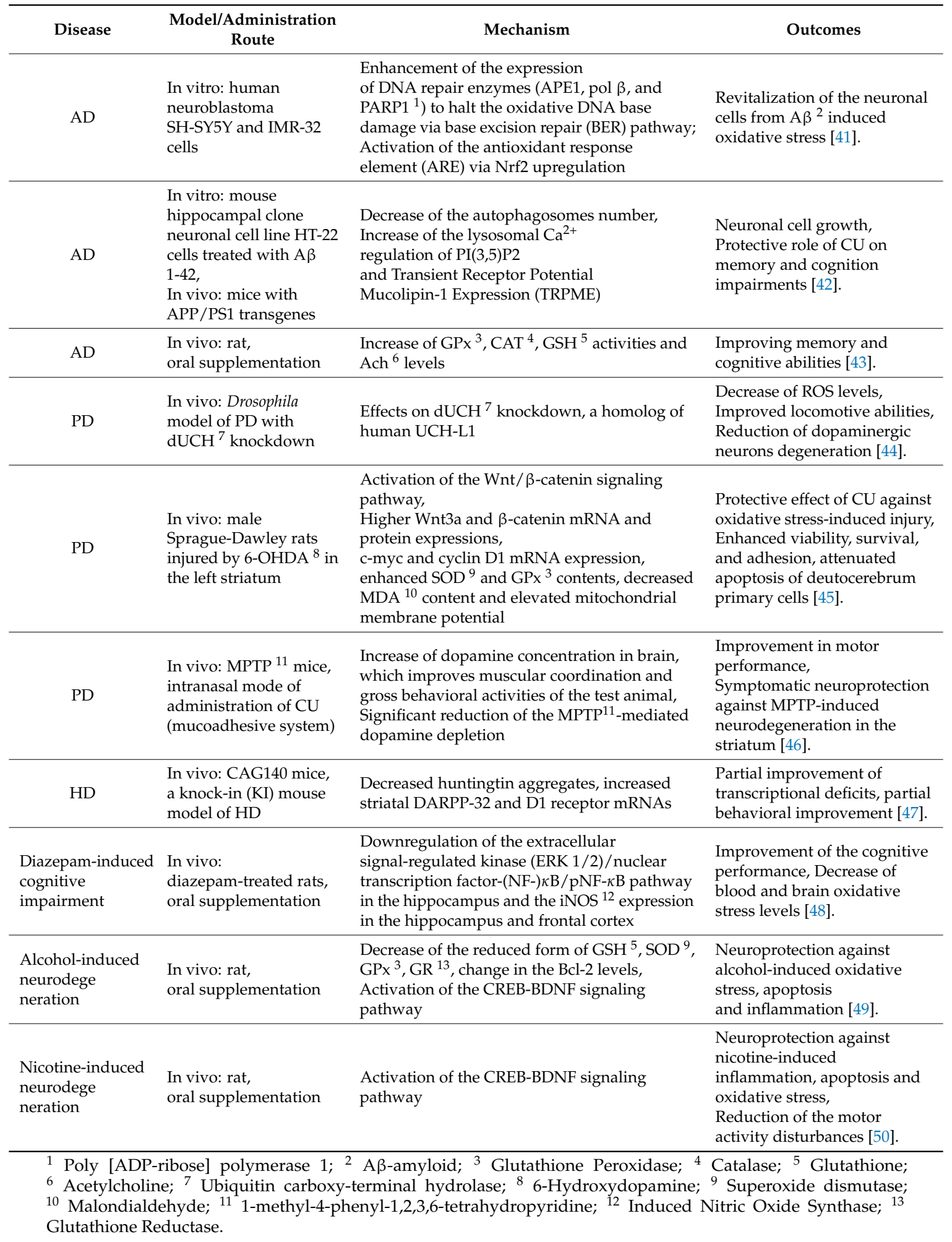

\subsection{Clinical Trials and Curcumin Limits}

A serious obstacle to the pharmaceutical application of curcumin has arisen from its limited water-solubility and low bioavailability. In addition, this compound is chemically instable, which may cause a loss of biological activities. The failure of free curcumin in clinical trials is likely due to its 
limited bioavailability. For instance, curcumin has been delivered in doses between 1 and $4 \mathrm{~g} /$ per day as capsules or as powder mixed with food in trials for treatment of Alzheimer's disease patients. The performed 6-month treatment study found no differences in the A $\beta$-amyloid levels between the treatment groups or in the Mini Mental State Examination (MMSE) scores [51]. Similarly, oral curcumin in a 24-week, randomized, double blind, and placebo-controlled study for AD treatment has shown no detectable differences in the measured biomarkers from the different treatment groups [52]. A clinical study with three single cases of patients receiving curcumin (100 mg/day) reported that only one patient increased his MMSE score from 12/30 to 17/30 after 12 weeks of treatment (improved calculation, concentration, transcription of the figure, and spontaneous writing). Two of the patients were on donepezil treatment before starting the curcumin trial [53]. Based on all performed trials with AD patients, it was, however, difficult to conclude if curcumin has positive effects on the AD symptoms [54].

In fact, the major fraction (35-89\%) of orally-administered curcumin can be lost due to its low bioavailability. The intestinal mucosa and mucus form a physical barrier to curcumin adsorption. The drug cannot reach the circulation in a bioactive form as it undergoes reduction and metabolism/conjugation in the liver. Reductases enzymatically reduce curcumin to dihydrocurcumin, tetrahydrocurcumin, and hexahydrocurcumin. Furthermore, curcumin may be conjugated to sulfates and glucuronides [55-57]. Thus, most of the circulating curcumin is in a conjugated form.

The necessity of the development of a delivery system for the protection of curcumin from rapid metabolism and for the improvement of its bioavailability has become evident [58]. A randomized, double-blind, placebo-controlled clinical trial examined the acute administration (effects $1 \mathrm{~h}$ and $3 \mathrm{~h}$ after a single dose application), chronic (4 weeks) administration, and acute-on-chronic ( $1 \mathrm{~h}$ or $3 \mathrm{~h}$ after a single dose followed by a chronic treatment) effects of solid-lipid-nanoparticle (SLNP) loaded by curcumin. The results of the SLNP formulation of curcumin ( $400 \mathrm{mg}$ in capsules Longvida ${ }^{\circledR}$ ) on cognitive function, mood, and blood biomarkers were obtained with 60 healthy adults (aged 60-85). SLNP-loaded curcumin significantly improved the performance in sustained attention and working memory tasks one hour after its administration (as compared to placebo). Working memory and mood (general fatigue and change in the calmness state, contentedness, and fatigue induced by psychological stress) were essentially improved following chronic treatment. A significant acute-on-chronic treatment effect on alertness and contentedness was also observed [59].

\section{Nanocarrier-Mediated Curcumin Delivery}

Nanotechnology for nanomedicine development employs functional materials with appropriate nanoscale organization that can interact with biological systems and induce desired physiological responses while minimizing undesirable side effects [60]. Nanotechnology-based delivery systems can influence drug capacity to cross the biological barriers (e.g., the BBB) and reach the targeted brain regions [58-61]. Therefore, nanocarriers are promising for the development of personalized medicines for the treatment of neurological disorders [62-67].

Lipid-based nanoparticles, including solid lipid nanoparticles (SLNPs), nanostructured lipid carriers (NLC), liposomes and liquid crystalline nanocarriers (LCN), as well as polymer-based nanoparticles (Figure 3), have been developed to overcome the poor solubility, stability, and bioavailability of curcumin, and to promote its utilization as a drug in disease treatments [68-124]. 


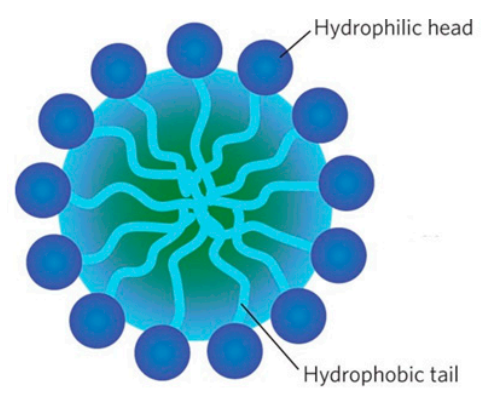

Micelles

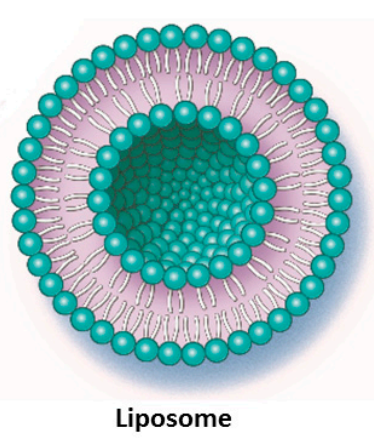

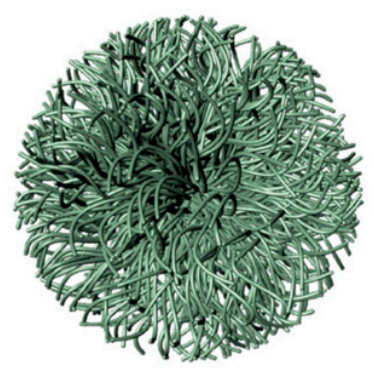

Polymeric nanoparticle

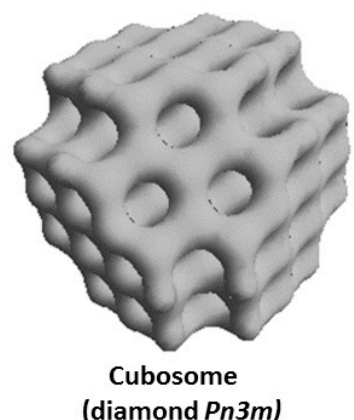

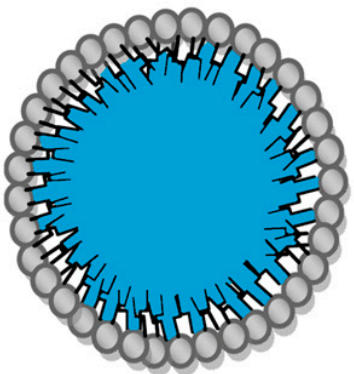

Solid lipid nanoparticle

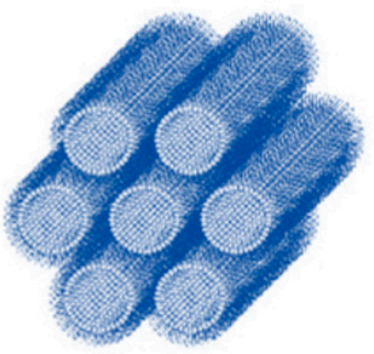

Hexosome

Figure 3. Schematic presentation of amphiphilic nanocarriers enabling the encapsulation and protection of hydrophobic and hydrophilic molecules of therapeutic significance.

Lipid-based nanoparticles have the advantage of being the least toxic carriers for in vivo applications. The lipids used to prepare biocompatible and biodegradable nanoparticles are usually naturally-occurring molecules with low acute and chronic toxicity. In the case of polymeric nanoparticles, the in vivo degradation of the polymer matrices might cause toxic effects [94]. The biocompatibility and the physico-chemical diversity of lipids and their capacity to enhance the oral bioavailability of drugs have made this kind of nanocarriers very attractive systems for drug delivery. As a matter of fact, lipid-based formulations may positively influence drug absorption in several ways, e.g., by influencing the solubilization properties, preventing the drug precipitation upon intestinal dilution, increasing the membrane permeability, inhibiting the efflux transporters, reducing the CYP enzymes, or enhancing the lymphatic transport [94,122].

Among the lipid-based nanoparticles, SLNPs have been intensively developed because they combine the advantages of different carrier systems like liposomes and polymeric particles. Similarly to liposomes, SLNPs are composed of physiologically-biocompatible excipients (lipids and fatty acids). In the same way to polymeric NPs, their solid matrix core can efficiently protect the loaded active pharmaceutical ingredient against chemical degradation under the harsh conditions of biological milieux. Therefore, SLNPs provide controlled release profiles of the encapsulated drugs [95].

In addition to the above advantages, liposomes can encapsulate and transport both lipophilic and hydrophilic drugs. They have a high degree of similarity to cell membranes in terms of lipid composition and organization, which facilitates the bioavailability of the pharmaceutical compounds [102]. Liquid crystalline nanocarriers (LCN) such as cubosomes and hexosomes (Figure 3) involve multiple compartments for encapsulation of either lipophilic or hydrophilic drugs. They display structural advantages which enable high encapsulation efficacy for molecules of various sizes and hydrophilicity $[113,116]$. LCNs are formed by self-assembly of lyotropic lipids such as unsaturated monoglycerides, phospholipids, glycolipids, and other amphiphilic molecules. For example, monoolein, which is a nontoxic, biodegradable, and biocompatible lipid, is classified as a GRAS (Generally Recognized As Safe), and $\omega-3$ polyunsaturated fatty acids (n-3 PUFA) have been shown to be highly beneficial in various disease models of neurodegeneration $[123,124]$.

In the following section, we summarize recently reported works on curcumin delivery to in vitro and in vivo models of neurodegenerative diseases. 


\subsection{Curcumin Delivery by Polymeric Nanoparticles}

Polymeric nanoparticles of a biocompatible and biodegradable nature are of essential interest as drug delivery nanocarriers. The release of the encapsulated drug can be modulated by altering the polymer composition and amphiphilicity. Poly(lactic-co-glycolic acid) (PLGA) is one of the most commonly-used biodegradable synthetic polymers. It is a FDA- (US) and EMA-approved platform for the delivery of drugs to humans. PLGA-derived nanoparticles have been successfully used for the encapsulation of different hydrophobic compounds (such as curcumin) by nanoprecipitation or by single emulsion techniques [71]. Hydrophilic molecules can be encapsulated by means of double emulsions or by two-step nanoprecipitation methods. On the other site, polymeric micelles have been studied towards site-specific drug delivery [68-70].

Micelles are formed by amphiphilic macromolecules, which self-assemble into nano-sized (10-100 nm in diameter) core/shell structures in excess aqueous media (Figure 3, top). The core-shell organization facilitates the incorporation of curcumin inside the hydrophobic core, while the water solubility of the nanocarriers is ensured by their hydrophilic corona [68]. Amphiphilic co-polymers self-assemble into micelles in aqueous solutions due to the hydrophobic interactions among their water-insoluble segments. Curcumin-loaded polymeric micelles have received attention due to various features (Table 3), like (i) the enhanced solubility of the drug; (ii) the sustained CU release profile; and (iii) the small size of the PEG-decorated carriers $(<200 \mathrm{~nm})$, which stabilizes them in biological fluids [64-66]. Micelles formed by the PLGA-PEG-PLGA synthetic copolymer have shown potential in modifying the pharmacokinetics and tissue distribution of curcumin. Evaluation of pharmacokinetics and biodistribution has demonstrated a prolonged half-life of the CU-micelles and a more efficient drug delivery to brain areas as compared to the carrier-free CU administration [71].

Table 3. Curcumin-loaded polymeric nanoparticles studied in in vitro and in vivo models of neurodegenerative diseases.

\begin{tabular}{|c|c|c|c|}
\hline Disease & Nanoformulation Type & $\begin{array}{l}\text { Model/Administration } \\
\text { Route }\end{array}$ & Outcomes \\
\hline $\mathrm{AD}$ & PLGA ${ }^{1}$ nanoparticles & $\begin{array}{l}\text { In vitro: SK-N-SH human } \\
\text { neuroblastoma cells }\end{array}$ & $\begin{array}{l}\text { Protection against } \mathrm{H}_{2} \mathrm{O}_{2} \text {-induced oxidative } \\
\text { damage [70]. }\end{array}$ \\
\hline $\mathrm{AD}$ & PLGA nanoparticles & $\begin{array}{l}\text { In vitro: Neural stem cells, } \\
\text { In vivo: } A \beta^{2} \text {-amyloid } \\
\text { induced rat model of } \\
\text { AD-like phenotypes }\end{array}$ & $\begin{array}{l}\text { Expression of genes involved in neuronal } \\
\text { proliferation and differentiation, } \\
\text { Reverse learning and memory } \\
\text { impairments [73]. }\end{array}$ \\
\hline $\mathrm{AD}$ & $\begin{array}{l}\text { PLGA nanoparticles } \\
\text { conjugated with Tet-1 } \\
\text { peptide }\end{array}$ & In vitro & $\begin{array}{l}\text { Anti-amyloid activity unchanged, decrease } \\
\text { of aggregates size [74], Diminution of } \\
\text { anti-oxidant activity. }\end{array}$ \\
\hline $\mathrm{AD}$ & $\begin{array}{l}\text { PLGA nanoparticles } \\
\text { functionalized with } \\
\text { glutathione }\end{array}$ & In vitro: in SK-N-SH cells & $\begin{array}{l}\text { Neuronal uptake, } \\
\text { Enhanced curcumin action }[75,76] \text {. }\end{array}$ \\
\hline $\mathrm{AD}$ & PLGA nanoparticles & In vivo: Rat, IV, oral & $\begin{array}{l}\text { Increased CU bioavailability and plasma } \\
\text { concentration [77]. }\end{array}$ \\
\hline $\mathrm{AD}$ & PLGA nanoparticles & In vivo: Rat & $\begin{array}{l}\text { Prolonged CU retention time in cerebral } \\
\text { cortex and hippocampus [78]. }\end{array}$ \\
\hline $\mathrm{AD}$ & $\begin{array}{l}\text { Apolipoprotein } \\
\text { E3-mediated } \\
\text { poly(butyl)cyano } \\
\text { acrylate nanoparticles }\end{array}$ & In vitro: SH-SY5Y cells & $\begin{array}{l}\text { Protection against } \mathrm{A} \beta \text {-induced } \\
\text { cytotoxicity [79]. }\end{array}$ \\
\hline $\mathrm{AD}$ & $\begin{array}{l}\text { Pegylated poly(alkyl } \\
\text { cyanoacrylate) } \\
\text { nanoparticles with } \\
\text { anti-A } \beta 1-42 \text { antibody at } \\
\text { the surface }\end{array}$ & In vitro & Inhibition of $A \beta$ aggregation [80]. \\
\hline
\end{tabular}


Table 3. Cont.

\begin{tabular}{|c|c|c|c|}
\hline Disease & Nanoformulation Type & $\begin{array}{l}\text { Model/Administration } \\
\text { Route }\end{array}$ & Outcomes \\
\hline $\mathrm{AD}$ & $\begin{array}{l}\text { Spherical (SPNs) or } \\
\text { Discoidal (DPNs) } \\
\text { polymeric nanocontructs } \\
\text { PLGA, DSPE-PEG }^{3}\end{array}$ & $\begin{array}{l}\text { In vitro: Raw } 264.7 \text { cells } \\
\text { In vitro production of } A \beta \\
\text { fibers }\end{array}$ & $\begin{array}{l}\text { Decrease of the pro-inflammatory cytokines } \\
\text { in macrophages stimulated via A } \beta \\
\text { fibers [81] }\end{array}$ \\
\hline $\mathrm{AD}$ & $\begin{array}{l}\text { Polymeric nanoparticles } \\
\text { (NanoCurc }^{\mathrm{TM}} \text { ) }\end{array}$ & $\begin{array}{l}\text { In vitro: SK-N-SH } \\
\text { differentiated cells } \\
\text { In vivo: Mice, parenteral } \\
\text { injection }\end{array}$ & $\begin{array}{l}\text { Protection against } \mathrm{H}_{2} \mathrm{O}_{2} \text {-induced } \\
\text { oxidative stress, } \\
\text { Downregulation of caspase } 3 \text { and } 7 \\
\text { activities, mediators of the } \\
\text { apoptotic pathway, } \\
\text { Increased glutathione levels [82]. }\end{array}$ \\
\hline $\mathrm{AD}$ & $\begin{array}{l}\text { Nanocurcumin } \\
\text { CU within polyethylene } \\
\text { glycol-polylactide } \\
\text { diblock polymer micelles }\end{array}$ & $\begin{array}{l}\text { In vitro } \\
\text { In vivo: AD model Tg2576 } \\
\text { mice }\end{array}$ & $\begin{array}{l}\text { Higher curcumin concentration in plasma, } \\
6 \text { times higher area under the curve and } \\
\text { mean residence time in brain than ordinary } \\
\text { CU, Improved memory function [83]. }\end{array}$ \\
\hline $\mathrm{AD}$ & Nanoemulsion & $\begin{array}{l}\text { In vitro: SK-N-SH cell line, } \\
\text { Sheep nasal mucosa }\end{array}$ & $\begin{array}{l}\text { Safe for intranasal delivery for brain } \\
\text { targeting, Higher flux and permeation } \\
\text { across sheep nasal mucosa [84]. }\end{array}$ \\
\hline $\begin{array}{l}\text { Mitochon drial } \\
\text { dysfunction in } \\
\text { brain aging }\end{array}$ & Micelles & $\begin{array}{l}\text { In vitro: PC12 cells In vivo: } \\
\text { NMRI mice; Ex vivo: } \\
\text { isolated mouse brain } \\
\text { mitochondria }\end{array}$ & $\begin{array}{l}\text { Improved bioavailability of native } \\
\text { curcumin around 10- to } 40 \text {-fold in plasma } \\
\text { and brain of mice, Prevention of } \\
\text { mitochondrial swelling in isolated mouse } \\
\text { brain mitochondria, Protection of PC12 } \\
\text { cells from nitrosative stress as compared to } \\
\text { free CU [85]. }\end{array}$ \\
\hline PD & Alginate nanocomposites & In vivo: Drosophila, oral & $\begin{array}{l}\text { Reduction of oxidative stress and apoptosis } \\
\text { in the brain [86]. }\end{array}$ \\
\hline
\end{tabular}

${ }^{1}$ Poly(lactic-co-glycolic acid); ${ }^{2} \mathrm{~A} \beta$-amyloid; ${ }^{3}$ Distearoy phosphatidylethanolamine-Polyethylene glycol.

\subsection{Curcumin Delivery by Lipid Nanoparticles}

\subsubsection{Solid Lipid Nanoparticles (SLNPs) and Nanostructured Lipid Carriers (NLCs)}

Solid lipid nanoparticles (SLNPs) are submicron colloidal lipid carriers (from $50 \mathrm{~nm}$ to $1000 \mathrm{~nm}$ in diameter) which maintain a solid, spherical shape at room temperature. They possess a solid lipid core matrix stabilized by emulsifiers that can solubilize lipophilic molecules. The CU-SLNPs are usually small, ranging from 100 to $300 \mathrm{~nm}$ in diameter. The total drug content can reach up to $92 \%$ when the SLNPs are manufactured using the micro-emulsification technique [87]. In an experimental rat model of cerebral ischemic reperfusion injury, animals fed with CU-loaded SLNPs have had a 90\% improvement in their cognitive function along with a $52 \%$ inhibition of the acetyl cholinesterase activity [88]. The investigated formula has been shown to increase the levels of superoxide dismutase (SOD), catalase (CAT), glutathione (GSH), and the activities of mitochondrial enzymes, while decreasing the lipid peroxidation and the peroxynitrite levels. Furthermore, this formulation showed a 16.4 to 30-fold improvement in the bioavailability of CU in the brain upon oral and intravenous (IV) administrations, respectively [88]. The product Longvida ${ }^{\circledR}$ (Verdure Sciences Inc.) is a SLNP-formulation of curcumin which can yield from 0.1 to $0.2 \mu \mathrm{M}$ plasma levels of $\mathrm{CU}$ with associated 1-2 $\mu \mathrm{M}$ brain levels of free $\mathrm{CU}$ in animals [89-91]. This formula was later optimized as "lipidated Cur", which can yield more than $5 \mu \mathrm{M}$ CU in mouse brain [93]. Other formulations of CU-loaded SLNPs, tested in Alzheimer's disease models, are outlined in Table 4. 
Table 4. Curcumin-loaded lipid nanoparticles studied in in vitro and in vivo models of neurodegenerative diseases.

\begin{tabular}{|c|c|c|c|}
\hline Disease & Nanoformulation Type & Model/Administration Route & Outcomes \\
\hline $\mathrm{AD}$ & Solid lipid nanoparticles & $\begin{array}{l}\text { In vitro: Mouse } \\
\text { neuroblastoma cells after } A \beta^{1} \\
\text { exposure }\end{array}$ & $\begin{array}{l}\text { Decreased ROS production, } \\
\text { Prevented apoptotic death, } \\
\text { Inhibition of Tau formation }[89,90] \text {. }\end{array}$ \\
\hline $\mathrm{AD}$ & $\begin{array}{l}\text { Solid lipid curcumin particle } \\
\text { (SLCP), Longvida }{ }^{\circledR}\end{array}$ & $\begin{array}{l}\text { In vitro: lipopolysaccharide } \\
\text { (LPS)-stimulated RAW } 264.7 \\
\text { cultured murine macrophages. }\end{array}$ & $\begin{array}{l}\text { Improved solubility over unformulated } \\
\text { curcumin, } \\
\text { Decreased LPS induced pro-inflammatory } \\
\text { mediators NO, PGE2, and IL-6 by } \\
\text { inhibiting the activation of NF-kB [92]. }\end{array}$ \\
\hline $\mathrm{AD}$ & $\begin{array}{l}\text { Solid lipid particleswith CU } \\
\text { (SLCP) }\end{array}$ & $\begin{array}{l}\text { In vivo: one-year-old } \\
\text { 5xFAD-and age-matched } \\
\text { wild-type mice, } \\
\text { intraperitoneal injections of } \\
\text { CU/SLCP }\end{array}$ & $\begin{array}{l}\text { Decrease in } \mathrm{A} \beta \text { plaque loads in dentate } \\
\text { gyrus of hippocampus, } \\
\text { More anti-amyloid, anti-inflammatory, and } \\
\text { neuroprotective [91]. }\end{array}$ \\
\hline $\mathrm{AD}$ & Solid lipid nanoparticles & In vivo: Rat, oral & Effective delivery across the BBB ${ }^{2}$ [88]. \\
\hline HD & $\begin{array}{l}\text { Solid lipid nanoparticles } \\
\text { (CU-SLNs) }\end{array}$ & $\begin{array}{l}\text { In vivo: (3-NP)-induced HD in } \\
\text { rats }\end{array}$ & $\begin{array}{l}\text { Restored glutathione levels and superoxide } \\
\text { dismutase activity, } \\
\text { Activation of nuclear factor-erythroid } 2 \\
\text { antioxidant pathway, } \\
\text { Reduction in mitochondrial swelling, lipid } \\
\text { peroxidation, protein carbonyls and } \\
\text { reactive oxygen species [89]. }\end{array}$ \\
\hline $\begin{array}{l}\text { CNS } \\
\text { disorders }\end{array}$ & $\begin{array}{l}\text { Solid lipid nanoparticles } \\
\text { (CU-SLNs) and } \\
\text { nanostructured lipid carriers } \\
\text { (CU-NLCs) }\end{array}$ & $\begin{array}{l}\text { In vivo: male } \\
\text { Sprague-Dawley rats } 6-8 \\
\text { weeks old, oral }\end{array}$ & $\begin{array}{l}\text { Enhanced curcumin brain uptake, } \\
\text { Cur-NLCs enhance the absorption of brain } \\
\text { curcumin more than } 4 \text {-folds in comparison } \\
\text { with Cur-SLNs [95]. }\end{array}$ \\
\hline $\mathrm{AD}$ & $\begin{array}{l}\text { Lipoprotein (LDL)-mimic } \\
\text { nanostructured lipid carrier } \\
\text { (NLC) modified with } \\
\text { lactoferrin (Lf) and loaded } \\
\text { with CU }\end{array}$ & In vivo: Rat, oral & $\begin{array}{l}\text { Cellular uptake mediated by the Lf receptor, } \\
\text { Permeability through the BBB and } \\
\text { preferentially accumulation in the brain, } \\
\text { Efficacy in controlling the damage } \\
\text { associated with AD [96]. }\end{array}$ \\
\hline $\mathrm{AD}$ & $\begin{array}{l}\text { Liposomes functionalized } \\
\text { with TAT-peptide }\end{array}$ & In vitro & Permeability across the BBB enhanced [98]. \\
\hline $\mathrm{AD}$ & $\begin{array}{l}\text { Liposomes containing } \\
\text { cardiolipin }\end{array}$ & In vitro: SK-N-MC cells & $\begin{array}{l}\text { Inhibition of the phosphorylation of } \mathrm{p} 38 \text {, } \\
\text { JNK, and tau protein, } \\
\text { Protection against serious degeneration of } \\
A \beta \text { insulted neurons [101]. }\end{array}$ \\
\hline $\mathrm{AD}$ & $\begin{array}{l}\text { WGA }{ }^{3} \text {-conjugated and } \\
\text { cardiolipin-incorporated } \\
\text { liposomes carrying } \mathrm{NGF}^{4} \text { and } \\
\text { CU }\end{array}$ & $\begin{array}{l}\text { In vitro: Human astrocytes } \\
\text { and to protect SK-N-MC cells } \\
\text { Apoptosis induced by } \\
\beta \text {-amyloid1-42 (A } \beta \text { 1-42) } \\
\text { fibrils }\end{array}$ & $\begin{array}{l}\text { Increased entrapment efficiency of NGF } \\
\text { and CU, of NGF release and cell viability, } \\
\text { Decreased release of CU, } \\
\text { Permeability of NGF and CU across the } \\
\text { blood-brain barrier [102]. }\end{array}$ \\
\hline $\mathrm{AD}$ & Liposomes & $\begin{array}{l}\text { In vivo: Mice, stereotaxic } \\
\text { injection in the right } \\
\text { hippocampus and neocortex }\end{array}$ & Decrease in $A \beta$ secretion and toxicity [97]. \\
\hline $\mathrm{AD}$ & $\begin{array}{l}\text { Liposomes decorated with } \\
\text { anti-transferrin receptor } \mathrm{mAb}\end{array}$ & $\begin{array}{l}\text { In vivo injection, } \\
\text { hippocampus and neocortex }\end{array}$ & $\begin{array}{l}\text { Decrease in A } \beta 1-42 \text { aggregation, } \\
\text { Internalization in the BBB model [99]. }\end{array}$ \\
\hline $\mathrm{AD}$ & $\begin{array}{l}\text { Liposomes functionalized } \\
\text { with a curcumin-alkyne } \\
\text { derivative TREG }\end{array}$ & $\begin{array}{l}\text { Human biological fluids from } \\
\text { sporadic AD patients and } \\
\text { down syndrome subjects }\end{array}$ & Sequestration of $A \beta 1-42[100,101]$. \\
\hline $\begin{array}{l}\text { Neuronal } \\
\text { loss }\end{array}$ & $\begin{array}{l}\text { Liquid-crystalline lipid } \\
\text { nanoparticles carrying } \\
\text { curcumin and DHA }\end{array}$ & In vitro: SH-SY5Y cells & $\begin{array}{l}\text { Neuronal viability and neurite outgrowth } \\
\text { by activation of the TrkB receptor signaling, } \\
\text { and promotion of phosphorylated CREB } \\
\text { protein expression [118]. }\end{array}$ \\
\hline $\mathrm{AD}$ & $\begin{array}{l}\text { Lipopeptide: a short } \\
\text { microtubule- stabilizing } \\
\text { peptide conjugated to a } \\
\text { hydrophobic palmitic acid } \\
\text { chain }\end{array}$ & $\begin{array}{l}\text { In vitro: Neuro-2a cells, } \\
\text { PC-12 differentiated cells }\end{array}$ & $\begin{array}{l}\text { Neurite outgrowth in absence of external } \\
\text { growth factors, } \\
\text { Neural cells morphology and health } \\
\text { amelioration }[120,121] \text {. }\end{array}$ \\
\hline
\end{tabular}


Nanostructured lipid carriers (NLC) are referred to as the "second generation" of SLNPs. NLCs are composed of mixtures of sterically different amphiphilic molecules. Often, mixtures of liquid-phase lipids and solid-phase lipids yield matrices with imperfections, which may incorporate increased quantities of drug molecules as compared to the SLNPs. Despite of the presence of the liquid-phase lipid, the NLC matrix appears to be in a solid state at room and body temperatures. The solid state is controlled by the fraction of the included liquid-phase lipid [94]. Sadegh-Malvajerd et al. have reported an enhanced entrapment efficiency of curcumin in NLCs $(94 \% \pm 0.74)$ as compared to SLNPs $(82 \% \pm 0.49)$. The pharmacokinetic studies, performed after intravenous (IV) administration of $4 \mathrm{mg} / \mathrm{kg}$ dose of curcumin in rats, have indicated that the amount of curcumin available in the brain was significantly higher for curcumin-loaded NLCs $\left(\mathrm{AUC}_{0-\mathrm{t}}=505.76 \mathrm{ng} / \mathrm{g} \mathrm{h}\right)$ as compared to free curcumin $\left(\mathrm{AUC}_{0-\mathrm{t}}=0.00 \mathrm{ng} / \mathrm{g} \mathrm{h}\right)$ and curcumin-loaded SLNs $\left(\mathrm{AUC}_{0-\mathrm{t}}=116.31 \mathrm{ng} / \mathrm{g} \mathrm{h}\right)(P<0.005)$ [95]. The outcomes of other recent investigations of CU-loaded NLCs in models of neurodegenerative diseases are summarized in Table 4.

\subsubsection{Liposomes}

Liposomes are lipid bilayer-based, self-assembled, closed colloidal structures, typically $25 \mathrm{~nm}$ to $5 \mu \mathrm{m}$ in diameter [97]. They usually have a spherical shape comprising an aqueous core surrounded by a hydrophobic lipid membrane (Figure 3). The lipid bilayer can be loaded with hydrophobic or amphiphilic molecules, whereas the hydrophilic molecules can be encapsulated in the aqueous reservoir of the liposomes. Often, liposomes are composed of phospholipids (e.g., phosphatidylcholines) or mixtures of phospholipids with co-lipids. Various liposome architectures can form depending on the preparation methods; for instance, multilamellar vesicles (MLV, involving a stack of several lipid bilayers), small unilamellar vesicles (SUV, constituted by a single lipid bilayer), large unilamellar vesicles (LUV), tubular vesicles, and cochleate vesicles.

Curcumin encapsulated in liposomes has been proven to be a safe formulation, which enhances the CU solubility and its cellular uptake [97-101]. Liposomes deliver CU into the cells via membrane fusion or endocytosis process. Liposomal formulations with a PEG surface coating provide a longer circulation time for the encapsulated drug. Biomolecular ligands can be anchored to the liposome surface in order to enhance the receptor targeting capacity, and hence, the permeability across the brain-blood barrier (BBB) $[102,103]$. The outcomes of the investigated CU-loaded liposomes in models of neurodegenerative diseases are summarized in Table 4.

\subsubsection{Liquid Crystalline Nanoparticles (LCNPs) with Internal Structure}

Liquid crystalline nanoparticles (LCNPs) are self-assembled architectures of lyotropic lipids, co-lipids (surfactants or oils), and water. They are typically formed upon dispersion and fragmentation of bulk lyotropic liquid crystalline phases (e.g., bicontinuous cubic, sponge, or inverted hexagonal phases) [104-106]. The amphiphilic molecules spontaneously organize into compartments with hydrophobic and hydrophilic domains (Figure 3), which can encapsulate lipophilic or hydrosoluble guest compounds. The structures formed by this self-assembly process are thermodynamically stable. The initial liquid crystalline phases are usually viscous and have a short-range order in comparison to solids, but long-range order in comparison to liquids. A typical example of a lyotropic liquid crystalline phase is the inverted bicontinuous cubic phase formed upon mixing of unsaturated monoglyceride lipids with water [105]. Cubosomes are produced upon dispersion of the bicontinuous cubic liquid crystalline phases in excess aqueous medium. Their periodic structures comprise folded bicontinuous lipid bilayer membranes and periodic networks of aqueous channels (Figure 3). The latter enable high encapsulation capacity for hydrophilic guest macromolecules [106-111]. Lipid nanocarriers of liquid crystalline internal structures have received considerable attention as delivery vehicles through the BBB [111,112].

Curcumin has been successfully entrapped into monolein-based LCNPs with almost $100 \%$ encapsulation efficiency [113]. LCNPs dispersion was very stable in terms of nanocarrier sizes 
and surface charge upon storage. LCNPs were efficiently taken up by cultures cells following the sustained release of curcumin. In addition, they provided inhibition of the cell proliferation and apoptosis induction in an anticancer study [113]. A recent investigation of an inverse hexagonal $\left(\mathrm{H}_{\mathrm{II}}\right)$ liquid crystalline phase encapsulating curcumin has demonstrated that the release of curcumin was a concentration-diffusion controlled process in the early stages, whereas multiple diffusion mechanisms coexisted in the later stages of drug release. Radical scavenging experiments have shown that curcumin-loaded LCNPs exert the desired antioxidant activity [114]. Thus, curcumin-loaded LCNPs may be promising for neurodegenerative disease treatments using sustained-release nanoformulations for combination therapies $[115,116]$. Further results obtained with lipid-based LCNPs in models of neurodegenerative disease are presented in Table 4.

\section{Conclusions}

The naturally occurring compound curcumin is increasingly studied in neurodegenerative disease models due to its neurogenesis-stimulating properties and its anti-amyloid and anti-tau potential. Nanotechnology-based delivery systems of curcumin have been developed with the purpose of improving its solubility, stability, and bioavailability in potential treatment strategies of neurodegenerative disorders. We summarized recent advances in research on safe liquid crystalline lipid-based nanocarriers (cubosome, spongosome, hexosome, and liposome particles) and solid lipid nanoparticles, as well as on selected biodegradable polymer-based nanocarriers. The emphasis is given on the observed biological outcomes of the curcumin nanoformulations in in vitro and in vivo models of the multifactor neurodegenerative diseases (AD, PD, HD and ALS). Despite the difficulty of overcoming biological barriers, promising results on the enhancement of the permeability of the $\mathrm{BBB}$ and receptor-mediated delivery across the BBB have been reported with liposome and cubosome nanocarriers. Further investigations will be required in order to understand the involved mechanisms of action of curcumin nanoformulations in the proposed neurodegenerative disease models, and to optimize the delivery systems and strategies towards translation into clinics.

Funding: This research was funded by the IDEX Paris-Saclay grant number ANR-11-IDEX-0003-02.

Acknowledgments: This work is supported by the "IDI 2017" project funded by the IDEX Paris-Saclay, ANR-11-IDEX-0003-02. M.R. thanks S. Lesieur for helpful advices during the doctoral study.

Conflicts of Interest: The authors declare no conflict of interest.

\section{Abbreviations}

$\begin{array}{ll}\text { A } \beta & \text { Amyloid } \beta \text { eta } \\ \text { ACh } & \text { Acetylcholine } \\ \text { AD } & \text { Alzheimer's disease } \\ \text { ALS } & \text { Amyotrophic lateral sclerosis } \\ \text { ApoE } & \text { Apolipoprotein E } \\ \text { APP } & \text { Amyloid beta precursor protein } \\ \text { ARE } & \text { Antioxidant response element } \\ \text { BBB } & \text { Brain blood barrier } \\ \text { BDNF } & \text { Brain derived neurotrophic factor } \\ \text { Ca }{ }^{2+} & \text { Calcium ion } \\ \text { CAT } & \text { Catalase } \\ \text { CHCHD2 } & \text { Coiled-coil-helix-coiled-coil-helix domain } 2 \\ \text { C9ORF72 } & \text { Chromosome } 9 \text { open reading frame } 72 \\ \text { COMT } & \text { Catechol-O-methyltransferase } \\ \text { CREB } & \text { cAMP (Cyclic adenosine monophosphate response) element-binding protein } \\ \text { CU } & \text { Curcumin } \\ \text { CYP } & \text { Cytochrome P450 } \\ \text { DARPP } & \text { Dopamine and adenosine } 3^{\prime}, 5^{\prime} \text {-monophosphate-regulated phosphoprotein }\end{array}$


DHA Docosahexaenoic acid

DNA Deoxyribonucleic acid acid

DNAJC13 DNA J heat shock protein family (Hsp40) member C13

DSPE Distearoy phosphatidylethanolamine

EIF4G1 Eukaryotic translation initiation factor 4 gamma 1

EMA European medicines agency

ERK Extracellular signal regulated kinase

FDA Food and drug administration

FUS RNA binding protein Fused in Sarcoma

GBA Glucocerebrosidase

GRAS Generally recognized as safe

GPx Glutathione peroxidase

GR Glutathione reductase

GSH Glutathione

HEWL Hen Egg White Lysozyme

HD Huntington disease

$\mathrm{H}_{2} \mathrm{O}_{2} \quad$ Hydrogen peroxide

HTT Huntingtin

IL-6 Interleukin 6

iNOS induced nitric oxide synthase

IV intravenous

JNK Jun N-terminal kinase

LCNs Liquid crystalline nanocarriers

LDL Low density lipoprotein

Lf Lactoferrin

LPS Lipopolysaccharide

LRRK1 Leucine-rich repeat kinase 1

LUV Large unilamellar vesicles

MAO-B Monoamine oxidase type B

MDA Malondialdehyde

MLV Multilamellar vesicles

MPTP 1-methyl-4-phenyl-1,2,3,6-tetrahydropyridine

MMSE Mini Mental State Examination

mRNA Messenger Ribonucleic Acid

NF-kb Nuclear Factor Kappa Beta

NGF Nerve growth factor

NLC Nanostructured lipid carriers

NO Nitric oxide

NPs nanoparticles

Nrf2 Nuclear factor erythroid 2-related factor 2

NSAIDs Non-steroidal anti-inflammatory drugs

OHDA 6 Hydroxydopamine

OPTN Optineurin

PD Parkinson disease

PEG Polyethylene glycol

PINK1 PTEN-induced putative kinase 1

PLGA Poly (lactic-co-glycolic acid)

PRKN Parkin

PSEN Presenilin

PUFA Polyunsaturated fatty acids

ROS Reactive oxygen species

SLCP Solid lipid curcumin nanoparticles

SLN Solid lipid nanoparticles

SOD1 Superoxide dismutase 1 


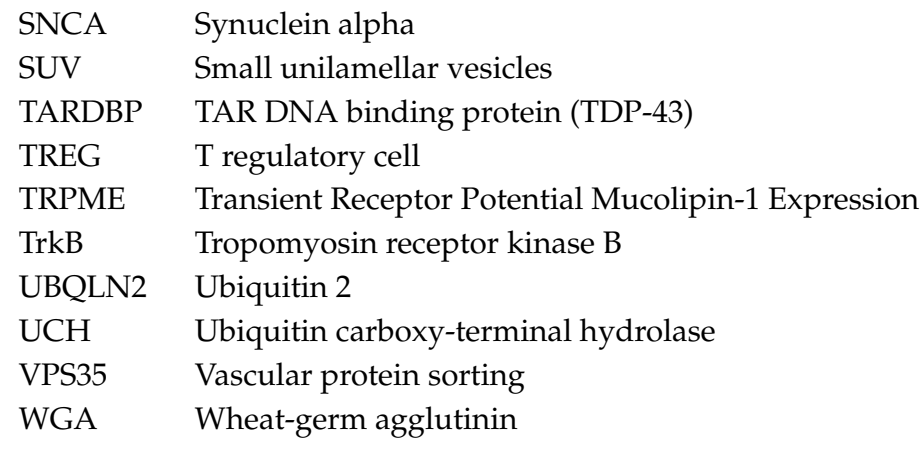

\section{References}

1. Brookmeyer, R.; Abdalla, N.; Kawas, C.H.; Corrada, M.M. Forecasting the prevalence of preclinical and clinical Alzheimer's disease in the United States. Alzheimers Dement. 2018, 14, 121-129. [CrossRef] [PubMed]

2. Jack, C.R.; Albert, M.S.; Knopman, D.S.; McKhann, G.M.; Sperling, R.A.; Carrillo, M.C.; Thies, B.; Phelps, C.H. Introduction to the recommendations from the National Institute on Aging-Alzheimer's Association workgroups on diagnostic guidelines for Alzheimer's disease. Alzheimers Dement. 2011, 7, 257-262. [CrossRef] [PubMed]

3. Haass, C.; Selkoe, D.J. Soluble protein oligomers in neurodegeneration: Lessons from the Alzheimer's amyloid beta-peptide. Nat. Rev. Mol. Cell Biol. 2007, 8, 101-112. [CrossRef] [PubMed]

4. Wakasaya, Y.; Kawarabayashi, T.; Watanabe, M.; Yamamoto-Watanabe, Y.; Takamura, A.; Kurata, T.; Murakami, T.; Abe, K.; Yamada, K.; Wakabayashi, K. Factors responsible for neurofibrillary tangles and neuronal cell losses in tauopathy. J. Neurosci. Res. 2011, 89, 576-584. [CrossRef] [PubMed]

5. Stoothoff, W.H.; Johnson, G.V. Tau phosphorylation: Physiological and pathological consequences. Biochim. Biophys. Acta 2005, 1739, 280-297. [CrossRef] [PubMed]

6. Wang, J.; Wang, Z.M.; Li, X.M.; Li, F.; Wu, J.J.; Kong, L.Y.; Wang, X.B. Synthesis and evaluation of multi-target-directed ligands for the treatment of Alzheimer's disease based on the fusion of donepezil and melatonin. Bioorgan. Med. Chem. 2016, 24, 4324-4338. [CrossRef] [PubMed]

7. Cole, G.M.; Morihara, T.; Lim, G.P.; Yang, F.; Begum, A.; Frautschy, S.A. NSAID and antioxidant prevention of Alzheimer's disease: Lessons from in vitro and animal models. Ann. N. Y. Acad. Sci. 2004, 1035, 68-84. [CrossRef] [PubMed]

8. Alexander, G.E. Biology of Parkinson's disease: Pathogenesis and pathophysiology of a multisystem neurodegenerative disorder. Dialogues Clin. Neurosci. 2004, 6, 259-280. [PubMed]

9. Dauer, W.; Przedborski, S. Parkinson's disease: Mechanisms and models. Neuron 2003, 39, 889-909. [CrossRef]

10. Landles, C.; Bates, G.P. Huntingtin and the molecular pathogenesis of Huntington's disease: Fourth in molecular medicine review series. EMBO Rep. 2004, 5, 958-963. [CrossRef] [PubMed]

11. Zuccato, C.; Marullo, M.; Vitali, B.; Tarditi, A.; Mariotti, C.; Valenza, M.; Lahiri, N.; Wild, E.J.; Sassone, J.; Ciammola, A. Brain-derived neurotrophic factor in patients with Huntington's disease. PLoS ONE 2011, 6, e22966. [CrossRef] [PubMed]

12. Zhou, S.; Zhou, Y.; Qian, S.; Chang, W.; Wang, L.; Fan, D. Amyotrophic lateral sclerosis in Beijing: Epidemiologic features and prognosis from 2010 to 2015. Brain Behav. 2018, 19, e01131. [CrossRef] [PubMed]

13. Glajch, E.; Ferraiuolo, L.; Mueller, K.A.; Stopford, M.J.; Prabhkar, V.; Gravanis, A.; Shaw, P.J.; Sadri-Vakili, G.S. Microneurotrophins improve survival in motor neuron-astrocyte co-cultures but co cot improve disease phenotypes in a mutant SOD1 mouse model of amyotrophic lateral sclerosis. PLoS ONE. 2016, 10, e0164103.

14. Varinderpal, S.D.; Michael, F. Mutations that affect mitochondrial functions and their association with neurodegenerative diseases. Mutat Res. Rev. Mutat. Res. 2014, 759, 1-13.

15. Barnham, K.J.; Masters, C.L.; Bush, A.I. Neurodegenerative diseases and oxidative stress. Nat. Rev. Drug Discov. 2004, 3, 205-214. [CrossRef] [PubMed]

16. Jiang, T.; Suna, Q.; Chena, S.B. Oxidative stress: A major pathogenesis and potential therapeutic target of antioxidative agents in Parkinson's disease and Alzheimer's disease. Progr. Neurobiol. 2016, 147, 1-19. [CrossRef] [PubMed] 
17. Gilgun-Sherki, Y.; Melamed, E.; Offen, D. Oxidative stress induced-neurodegenerative diseases: The need for antioxidants that penetrate the blood brain barrier. Neuropharmacology 2001, 40, 959-975. [CrossRef]

18. Uttara, B.; Singh, A.V.; Zamboni, P.; Mahajan, R.T. Oxidative stress and neurodegenerative diseases: A review of upstream and downstream antioxidant therapeutic options. Curr. Neuropharmacol. 2009, 7, 65-74. [CrossRef] [PubMed]

19. Dumont, M.; Beal, M.F. Neuroprotective strategies involving ROS in Alzheimer disease. Free Radic. Biol. Med. 2011, 51, 1014-1026. [CrossRef] [PubMed]

20. Zhong, L.; Zhou, J.; Chen, X.; Lou, Y.; Liu, D.; Zou, X.; Yang, B.; Yin, Y.; Pan, Y. Quantitative proteomics study of the neuroprotective effects of B12 on hydrogen peroxide-induced apoptosis in SH-SY5Y cells. Sci. Rep. 2016, 6, 22635. [CrossRef] [PubMed]

21. Onyango, I.G.; Khan, S.M.; Bennett, J.P. Mitochondria in the pathophysiology of Alzheimer's and Parkinson's diseases. Front. Biosci. 2017, 22, 854-872. [CrossRef]

22. Ankarcronaa, M.; Mangialascheb, F.; Winblada, B. Thinking Alzheimer's disease therapy: Are mitochondria the key? J. Alzheimers Dis. 2010, 20 (Suppl. 2), S579-S590. [CrossRef] [PubMed]

23. Federico, A.; Cardaioli, E.; Da Pozzo, P.; Formichi, P.; Gallus, G.N. Mitochondria, oxidative stress and neurodegeneration. J. Neurol. Sci. 2012, 322, 254-262. [CrossRef] [PubMed]

24. Stahon, K.E.; Bastian, C.; Griffith, S.; Kidd, G.J.; Brunet, S.; Baltan, S. Age-related changes in axonal and mitochondrial ultrastructure and function in white matter. J. Neurosci. 2016, 36, 9990-10001. [CrossRef] [PubMed]

25. Cho, D.H.; Nakamura, T.; Lipton, S.A. Mitochondrial dynamics in cell death and neurodegeneration. Cell Mol. Life Sci 2010, 67, 3435-3447. [CrossRef] [PubMed]

26. Lu, M.; Su, C.; Qiao, C.; Bian, Y.; Ding, J.; Hu, G. Metformin prevents dopaminergic neuron death in MPTP/P-induced mouse model of Parkinson's disease via autophagy and mitochondrial ROS clearance. Int. J. Neuropsychopharmacol. 2016, 19, 1-11. [CrossRef] [PubMed]

27. Zádori, D.; Klivényi, P.; Szalárdy, L.; Fülöp, F.; Toldi, J.; Vécsei, L. Mitochondrial disturbances, excitotoxicity, neuroinflammation and kynurenines: Novel therapeutic strategies for neurodegenerative disorders. J. Neurol. Sci. 2012, 322, 187-191. [CrossRef] [PubMed]

28. Rahimifard, M.; Maqbool, F.; Moeini-Nodeh, S.; Niaz, K.; Abdollahi, M.; Braidy, N.; Nabavi, S.M.; Nabavi, S.F. Targeting the TLR4 signaling pathway by polyphenols: A novel therapeutic strategy for neuroinflammation. Ageing Res. Rev. 2017, 36, 11-19. [CrossRef] [PubMed]

29. Géral, C.; Angelova, A.; Lesieur, S. From molecular to nanotechnology strategies for delivery of neurotrophins: Emphasis on brain-derived neurotrophic factor (BDNF). Pharmaceutics 2013, 5, 127-167. [CrossRef] [PubMed]

30. Angelova, A.; Angelov, B.; Drechsler, M.; Lesieur, S. Neurotrophin delivery using nanotechnology. Drug Discov. Today 2013, 18, 1263-1271. [CrossRef] [PubMed]

31. Devi, L.; Ohno, M. 7,8-Dihydroxyflavone, a small-molecule TrkB agonist, reverses memory deficits and BACE1 elevation in a mouse model of Alzheimer's disease. Neuropsychopharmacology 2012, 37, 434-444. [CrossRef] [PubMed]

32. Soleimani, V.; Sahebkar, A.; Hosseinzadeh, H. Turmeric (Curcuma longa) and its major constituent (curcumin) as nontoxic and safe substances. Review. Phytother. Res. 2018, 32, 985-995. [CrossRef] [PubMed]

33. Mahdavi, H.; Hadadi, Z.; Ahmadi, M.A. Review of the anti-oxidation, anti-inflammatory and anti-tumor properties of curcumin. Tradit. Integr. Med. 2017, 2, 188-195.

34. Gupta, S.C.; Patchva, S.; Aggarwal, B.B. Therapeutic roles of curcumin: Lessons learned from clinical trials. AAPS J. 2013, 15, 195-218. [CrossRef] [PubMed]

35. Brondino, N.; Re, S.; Boldrini, A.; Cuccomarino, A.; Lanati, N.; Barale, F.; Politi, P. Curcumin as a therapeutic agent in dementia: A mini systematic review of human studies. Sci. World J. 2014, 2014, 1-6. [CrossRef] [PubMed]

36. Serafini, M.M.; Catanzaro, M.; Rosini, M.; Racchi, M.; Lanni, C. Curcumin in Alzheimer's disease: Can we think to new strategies and perspectives for this molecule? Pharmacol. Res. 2017, 124, 146-155. [CrossRef] [PubMed]

37. Maiti, P.; Dunbar, G. Use of curcumin, a natural polyphenol for targeting molecular pathways in treating age-related neurodegenerative diseases. Int. J. Mol. Sci. 2018, 31, 19. [CrossRef] [PubMed] 
38. Haan, J.D.; Morrema, T.H.J.; Rozemuller, A.J.; Bouwman, F.H.; Hoozemans, J.J.M. Different curcumin forms selectively bind fibrillar amyloid beta in post mortem Alzheimer's disease brains: Implications for in-vivo diagnostics. Acta Neuropathol. Commun. 2018, 6, 75. [CrossRef] [PubMed]

39. Samarghandian, S.; Azimi-Nezhad, M.; Farkhondeh, T.; Samini, F. Anti-oxidative effects of curcumin on immobilization-induced oxidative stress in rat brain, liver and kidney. Biomed. Pharmacother. 2017, 87, 223-229. [CrossRef] [PubMed]

40. Ahmad, B.; Borana, M.S.; Chaudhary, A.P. Understanding curcumin-induced modulation of protein aggregation. Int. J. Biol. Macromol. 2017, 100, 89-96. [CrossRef] [PubMed]

41. Sarkar, B.; Dhiman, M.; Mittal, S.; Mantha, A.K. Curcumin revitalizes Amyloid beta (25-35)-induced and organophosphate pesticides pestered neurotoxicity in SH-SY5Y and IMR-32 cells via activation of APE1 and Nrf2. Metab. Brain Dis. 2017, 32, 2045-2061. [CrossRef] [PubMed]

42. Zhang, L.; Fang, Y.; Cheng, X.; Lian, Y.J.; Xu, H.L.; Zeng, Z.S.; Zhu, H.C. Curcumin exerts effects on the pathophysiology of Alzheimer's disease by regulating PI(3,5)P2 and transient receptor potential mucolipin-1 expression. Front. Neurol. 2017, 8, 531. [CrossRef] [PubMed]

43. Liaquat, L.; Batool, Z.; Sadir, S.; Rafiq, S.; Shahzad, S.; Perveen, T.; Haider, S. Naringenin-induced enhanced antioxidant defense system meliorates cholinergic neurotransmission and consolidates memory in male rats. Life Sci. 2018, 194, 213-223. [CrossRef] [PubMed]

44. Nguyen, T.T.; Vuu, M.D.; Huynh, M.A.; Yamaguchi, M.; Tran, L.T.; Dang, T.P.T. Curcumin effectively rescued Parkinson's disease-like phenotypes in a novel drosophila melanogaster model with dUCH Knockdown. Oxid. Med. Cell. Longev. 2018, 2018, 1-12. [CrossRef] [PubMed]

45. Wang, Y.L.; Ju, B.; Zhang, Y.Z.; Yin, H.L.; Liu, Y.J.; Wang, S.S.; Zeng, Z.L.; Yang, X.P.; Wang, H.T.; Li, J.F. Protective effect of curcumin against oxidative stress-induced injury in rats with Parkinson's disease through the Wnt/ $\beta$-catenin signaling pathway. Cell. Physiol. Biochem. 2017, 43, 2226-2241. [CrossRef] [PubMed]

46. Snigdha, D.M.; Surjyanarayan, M.; Jayvadan, P. Intranasal mucoadhesive microemulsion for neuroprotective effect of curcumin in mPTP induced Parkinson model. Braz. J. Pharm. Sci. 2017, 53. [CrossRef]

47. Hickey, M.A.; Zhu, C.; Medvedeva, V.; Lerner, R.P.; Patassini, S.; Franich, N.R.; Maiti, P.; Frautschy, S.A.; Zeitlin, S.; Levine, M.S.; et al. Improvement of neuropathology and transcriptional deficits in CAG 140 knock-in mice supports a beneficial effect of dietary curcumin in Huntington's disease. Mol. Neurodegener. 2012, 7, 12. [CrossRef] [PubMed]

48. Sevastre-Berghian, A.C.; Făgărăsan, V.; Toma, V.A.; Bâldea, I.; Olteanu, D.; Moldovan, R.; Decea, N.; Filip, G.A.; Clichici, S.V. Curcumin reverses the diazepam-induced cognitive impairment by modulation of oxidative stress and ERK 1/2/NF-кB pathway in brain. Oxid. Med. Cell. Longev. 2017, 2017, 1-16. [CrossRef] [PubMed]

49. Motaghinejad, M.; Motevalian, M.; Fatima, S.; Hashemi, H.; Gholami, M. Curcumin confers neuroprotection against alcohol-induced hippocampal neurodegeneration via CREB-BDNF pathway in rats. Biomed. Pharmacother. 2017, 87, 721-740. [CrossRef] [PubMed]

50. Motaghinejad, M.; Motevalian, M.; Fatima, S.; Faraji, F.; Mozaffari, S. The neuroprotective effect of curcumin against nicotine-induced neurotoxicity is mediated by CREB-BDNF signaling pathway. Neurochem. Res. 2017, 42, 2921-2932. [CrossRef] [PubMed]

51. Baum, L.; Lam, C.W.; Cheung, S.K.; Kwok, T.; Lui, V.; Tsoh, J.; Lam, L.; Leung, V.; Hui, E.; Ng, C. Six-month randomized, placebo-controlled, double-blind, pilot clinical trial of curcumin in patients with Alzheimer disease. J. Clin. Psychopharmacol. 2008, 28, 110-113. [CrossRef] [PubMed]

52. Ringman, J.M.; Frautschy, S.A.; Teng, E.; Begum, A.N.; Bardens, J.; Beigi, M.; Gylys, K.H.; Badmaev, V.; Heath, D.D.; Apostolova, L.G. Oral curcumin for Alzheimer's disease: Tolerability and efficacy in a 24-week randomized, double blind, placebo-controlled study. Alzheimers Res. Ther. 2012, 4, 43. [CrossRef] [PubMed]

53. Hishikawa, N.; Takahashi, Y.; Amakusa, Y.; Tanno, Y.; Tuji, Y.; Niwa, H.; Murakami, N.; Krishna, U.K. Effects of turmeric on Alzheimer's disease with behavioral and psychological symptoms of dementia. AYU 2012, 33, 499-504. [CrossRef] [PubMed]

54. Mazzanti, G.; Di Giacomo, S. Curcumin and resveratrol in the management of cognitive disorders: What is the clinical evidence? Molecules 2016, 21, 1243. [CrossRef] [PubMed]

55. Ireson, C.R.; Jones, D.J.; Orr, S.; Coughtrie, M.W.; Boocock, D.J.; Williams, M.L.; Farmer, P.B.; Steward, W.P.; Gescher, A.J. Metabolism of the cancer chemopreventive agent curcumin in human and rat intestine. Cancer Epidemiol. Biomark. Prev. 2002, 11, 105-111. 
56. Marczylo, T.H.; Steward, W.P.; Gescher, A.J. Rapid analysis of curcumin and curcumin metabolites in rat biomatrices using a novel ultraperformance liquid chromatography (UPLC) method. J. Agric. Food. Chem. 2009, 57, 797-803. [CrossRef] [PubMed]

57. Marczylo, T.H.; Verschoyle, R.D.; Cooke, D.N.; Morazzoni, P.; Steward, W.P.; Gescher, A.J. Comparison of systemic availability of curcumin with that of curcumin formulated with phosphatidylcholine. Cancer Chemother. Pharmacol. 2007, 60, 171-177. [CrossRef] [PubMed]

58. Ghalandarlaki, N.; Alizadeh, A.M.; Ashkani-Esfahani, S. Nanotechnology-applied curcumin for different diseases therapy. Biomed. Res. Int. 2014, 2014, 1-23. [CrossRef] [PubMed]

59. Cox, K.H.; Pipingas, A.; Scholey, A.B. Investigation of the effects of solid lipid curcumin on cognition and mood in a healthy older population. J. Psychopharmacol. 2015, 29, 642-651. [CrossRef] [PubMed]

60. Modi, G.; Pillay, V.; Choonara, Y.E. Advances in the treatment of neurodegenerative disorders employing nanotechnology. Ann. N. Y. Acad. Sci. 2010, 1184, 154-172. [CrossRef] [PubMed]

61. Sahni, J.K.; Doggui, S.; Ali, J.; Baboota, S.; Dao, L.; Ramassamy, C. Neurotherapeutic applications of nanoparticles in Alzheimer's disease. J. Control. Release 2011, 152, 208-231. [CrossRef] [PubMed]

62. Craparo, E.F.; Bondì, M.L.; Pitarresi, G.; Cavallaro, G. Nanoparticulate systems for drug delivery and targeting to the central nervous system. CNS Neurosci. Ther. 2011, 17, 670-677. [CrossRef] [PubMed]

63. Fonseca-Santos, B.; Gremiao, D.; Palmira, M.; Chorilli, M. Nanotechnology-based drug delivery systems for the treatment of Alzheimer's disease. Int. J. Nanomed. 2015, 10, 4981-5003. [CrossRef] [PubMed]

64. Kanwar, J.R.; Sun, X.; Punj, V.; Sriramoju, B.; Mohan, R.R.; Zhou, S.F.; Chauhan, A.; Kanwar, R.K. Nanoparticles in the treatment and diagnosis of neurological disorders: Untamed dragon with fire power to heal. Nanomedicine 2012, 8, 399-414. [CrossRef] [PubMed]

65. Gao, H. Progress and perspectives on targeting nanoparticles for brain drug delivery. Acta Pharm. Sin. B 2016, 6, 268-286. [CrossRef] [PubMed]

66. Roney, C.; Kulkarni, P.; Arora, V.; Antich, P.; Bonte, F.; Wu, A.; Mallikarjuana, N.N.; Manohar, S.; Liang, H.F.; Kulkarni, A.R.; et al. Targeted nanoparticles for drug delivery through the blood-brain barrier for Alzheimer's disease. J. Control. Release 2005, 108, 193-214. [CrossRef] [PubMed]

67. Modi, G.; Pillay, V.; Choonara, Y.E.; Ndesendo, V.M.K.; Du Toit, L.C.; Naidoo, D. Nanotechnological applications for the treatment of neurodegenerative disorders. Progr. Neurobiol. 2009, 4, 272-285. [CrossRef] [PubMed]

68. Ma, Z.; Haddadi, A.; Molavi, O.; Lavasanifar, A.; Lai, R.; Samuel, J. Micelles of poly(ethyleneoxide)-b-poly(epsilon-caprolactone) as vehicles for the solubilization, stabilization, and controlled delivery of curcumin. J. Biomed. Mater. Res. A 2008, 86, 300-310. [CrossRef] [PubMed]

69. Yu, H.; Li, J.; Shi, K.; Huang, Q. Structure of modified epsilon-polylysine micelles and their application in improving cellular antioxidant activity of curcuminoids. Food Funct. 2011, 2, 373-380. [CrossRef] [PubMed]

70. Podaralla, S.; Averineni, R.; Alqahtani, M.; Perumal, O. Synthesis of novel biodegradable methoxypoly (ethylene glycol)-zein micelles for effective delivery of curcumin. Mol. Pharm. 2012, 9, 2778-2786. [CrossRef] [PubMed]

71. Song, Z.; Feng, R.; Sun, M.; Guo, C.; Gao, Y.; Li, L.; Zhai, G. Curcumin-loaded PLGA-PEG-PLGA triblock copolymeric micelles: Preparation, pharmacokinetics and distribution in vivo. J. Colloid Interface Sci. 2011, 354, 116-123. [CrossRef] [PubMed]

72. Doggui, S.; Sahni, J.K.; Arseneault, M.; Dao, L.; Ramassamy, C. Neuronal uptake and neuroprotective effect of curcumin-loaded PLGA nanoparticles on the human SK-N-SH cell line. J. Alzheimers Dis. 2012, 30, 377-392. [CrossRef] [PubMed]

73. Tiwari, S.K.; Agarwal, S.; Seth, B.; Yadav, A.; Nair, S.; Bhatnagar, P.; Karmakar, M.; Kumari, M.; Chauhan, L.K.; Patel, D.K.; et al. Curcumin-loaded nanoparticles potently induce adult neurogenesis and reverse cognitive deficits in Alzheimer's disease model via canonical Wnt/ $\beta$-catenin pathway. ACS Nano 2014, 8, 76-103. [CrossRef] [PubMed]

74. Mathew, A.; Fukuda, T.; Nagaoka, Y.; Hasumura, T.; Morimoto, H.; Yoshida, Y.; Maekawa, T.; Venugopal, K.; Kumar, D.S. Curcumin loaded-PLGA nanoparticles conjugated with Tet-1 peptide for potential use in Alzheimer's disease. PLoS ONE 2012, 7, e32616. [CrossRef] [PubMed]

75. Paka, G.D.; Doggui, S.; Zaghmi, A.; Safar, R.; Dao, L.; Reisch, A.; Klymchenko, A.; Roullin, V.G.; Joubert, O.; Ramassamy, C. Neuronal uptake and neuroprotective properties of curcumin-loaded nanoparticles on SK-N-SH cell line: Role of poly(lactide-coglycolide) polymeric matrix composition. Mol. Pharm. 2016, 13, 391-403. [CrossRef] [PubMed] 
76. Paka, G.D.; Ramassamy, C. Optimization of curcumin-loaded PEG-PLGA nanoparticles by GSH functionalization: Investigation of the internalization pathway in neuronal cells. Mol. Pharm. 2017, 14, 93-106. [CrossRef] [PubMed]

77. Tsai, Y.M.; Jan, W.C.; Chien, C.F.; Lee, W.C.; Lin, L.C.; Tsai, T.H. Optimised nano-formulation on the bioavailability of hydrophobic polyphenol, curcumin, in freely-moving rats. Food Chem. 2011, 127, 918-925. [CrossRef] [PubMed]

78. Tsai, Y.M.; Chien, C.F.; Lin, L.C.; Tsai, T.H. Curcumin and its nano-formulation: The kinetics of tissue distribution and blood-brain barrier penetration. Int. J. Pharm. 2011, 416, 331-338. [CrossRef] [PubMed]

79. Mulik, R.S.; Mönkkönen, J.; Juvonen, R.O.; Mahadik, K.R.; Paradkar, A.R. ApoE3mediated poly (butyl) cyanoacrylate nanoparticles containing curcumin: Study of enhanced activity of curcumin against beta amyloid induced cytotoxicity using in vitro cell culture model. Mol. Pharm. 2010, 7, 815-825. [CrossRef] [PubMed]

80. Le Droumaguet, B.; Nicolas, J.; Brambilla, D.; Mura, S.; Maksimenko, A.; DeKimpe, L.; Salvati, E.; Zona, C.; Airoldi, C.; Canovi, M.; et al. Versatile and efficient targeting using a single nanoparticulate platform: Application to cancer and Alzheimer's disease. ACS Nano 2012, 6, 5866-5879. [CrossRef] [PubMed]

81. Ameruoso, A.; Palomba, R.; Palange, A.; Cervadoro, A.; Lee, A.; Di Mascolo, D.; Decuzzi, P. Ameliorating amyloid- $\beta$ fibrils triggered inflammation via curcumin-loaded polymeric nanoconstructs. Front. Immunol. 2017, 8, 1411. [CrossRef] [PubMed]

82. Ray, B.; Bisht, S.; Maitra, A.; Maitra, A.; Lahiri, D.K. Neuroprotective and neurorescue effects of a novel polymeric nanoparticle formulation of curcumin (NanoCurcTM) in the neuronal cell culture and animal model: Implications for Alzheimer's disease. J. Alzheimers Dis. 2011, 23, 61-77. [CrossRef] [PubMed]

83. Cheng, K.K.; Yeung, C.F.; Ho, S.W.; Chow, S.F.; Chow, A.H.; Baum, L. Highly stabilized curcumin nanoparticles tested in an in vitro blood-brain barrier model and in Alzheimer's disease Tg2576 mice. AAPS J. 2013, 15, 324-336. [CrossRef] [PubMed]

84. Sood, S.; Jain, K.; Gowthamarajan, K. Optimization of curcumin nanoemulsion for intranasal delivery using design of experiment and its toxicity assessment. Colloids Surf. B Biointerfaces 2014, 113, 330-337. [CrossRef] [PubMed]

85. Hagl, S.; Kocher, A.; Schiborr, C.; Kolesova, N.; Frank, J.; Eckert, G.P. Curcumin micelles improve mitochondrial function in neuronal PC12 cells and brains of NMRI mice-Impact on bioavailability. Neurochem. Int. 2015, 89, 234-242. [CrossRef] [PubMed]

86. Siddique, Y.H.; WasiKhan, S.B.R.; Naqvi, A.H. Synthesis of alginate-curcumin nanocomposite and its protective role in transgenic drosophila model of Parkinson's disease. ISRN Pharmacol. 2013, 2013, 1-8. [CrossRef] [PubMed]

87. Kakkar, V.; Muppu, S.K.; Chopra, K.; Kaur, I.P. Curcumin loaded solid lipid nanoparticles: An efficient formulation approach for cerebral ischemic reperfusion injury in rats. Eur. J. Pharm. Biopharm. 2013, 85, 339-345. [CrossRef] [PubMed]

88. Kakkara, V.; Mishrab, A.K.; Chuttanib, K.; Kaura, I.P. Proof of concept studies to confirm the delivery of curcumin loaded solid lipid nanoparticles (C-SLNs) to brain. Int. J. Pharm. 2013, 448, 354-359. [CrossRef] [PubMed]

89. Maiti, P.; Dunbar, G.L. Comparative neuroprotective effects of dietary curcumin and solid lipid curcumin particles in cultured mouse neuroblastoma cells after exposure to Abeta42. Int. J. Alzheimers Dis. 2017, 2017, 1-13. [CrossRef] [PubMed]

90. Maiti, P.; Hall, T.C.; Paladugu, L.; Kolli, N.; Learman, C.; Rossignol, J.; Dunbar, G.L. A comparative study of dietary curcumin, nanocurcumin, and other classical amyloid-binding dyes for labeling and imaging of amyloid plaques in brain tissue of 5x-familial Alzheimer's disease mice. Histochem. Cell Biol. 2016, 146, 609-625. [CrossRef] [PubMed]

91. Maiti, P.; Paladugu, L.; Dunbar, G.L. Solid lipid curcumin particles provide greater anti-amyloid, anti-inflammatory and neuroprotective effects than curcumin in the 5xFAD mouse model of Alzheimer's disease. BMC Neurosci. 2018, 19, 7. [CrossRef] [PubMed]

92. Pragati, P.; Nahar, A.; Slitt, L.; Navindra, P. Anti-inflammatory effects of novel standardized solid lipid curcumin formulations. J. Med. Food 2015, 18, 786-792. 
93. Dadhaniya, P.; Patel, C.; Muchhara, J.; Bhadja, N.; Mathuria, N.; Vachhani, K.; Soni, M.G. Safety assessment of a solid lipid curcumin particle preparation: Acute and subchronic toxicity studies. Food Chem. Toxicol. 2011, 49, 1834-1842. [CrossRef] [PubMed]

94. Ganesan, P.; Narayanasamy, D. Lipid nanoparticles: Different preparation techniques, characterization, hurdles, and strategies for the production of solid lipid nanoparticles and nanostructured lipid carriers for oral drug delivery. Sustain. Chem. Pharm. 2017, 6, 37-56. [CrossRef]

95. Sadegh-Malvajerd, S.; Azadi, A.; Izadi, Z.; Kurd, M.; Dara, T.; Dibaei, M.; Sharif-Zadeh, M.; Akbari-Javar, H.; Hamidi, M. Brain delivery of curcumin using solid lipid nanoparticles and nanostructured lipid carriers: Preparation, optimization, and pharmacokinetic evaluation. ACS Chem. Neurosci. 2018. [CrossRef] [PubMed]

96. Meng, F.; Asghar, S.; Gao, S.; Su, Z.; Song, J.; Huo, M.; Meng, W.; Ping, Q.; Xiao, Y. A novel LDL-mimic nanocarrier for the targeted delivery of curcumin into the brain to treat Alzheimer's disease. Colloids Surf. $B$ Biointerfaces 2015, 134, 88-97. [CrossRef] [PubMed]

97. Lazar, A.N.; Mourtas, S.; Youssef, I.; Parizot, C.; Dauphin, A.; Delatour, B.; Antimisiaris, S.G.; Duyckaerts, C. Curcumin-conjugated nanoliposomes with high affinity for $\mathrm{A} \beta$ deposits: Possible applications to Alzheimer disease. Nanomed. Nanotechnol. Biol. Med. 2013, 9, 712-721. [CrossRef] [PubMed]

98. Sancini, G.; Gregori, M.; Salvati, E.; Cambianica, L.; Re, F.; Ornaghi, F.; Canovi, M.; Fracasso, C.; Cagnotto, A.; Colombo, M.; et al. Functionalization with TAT-peptide enhances blood-brain barrier crossing in vitro of nanoliposomes carrying a curcumin-derivative to bind amyloid- $\beta$ peptide. J. Nanomed. Nanotechnol. 2013, 4, 1-8. [CrossRef]

99. Mourtas, S.; Canovi, M.; Zona, C.; Aurilia, D.; Niarakis, A.; La Ferla, B.; Salmona, M.; Nicotra, F.; Gobbi, M.; Antimisiaris, S.G. Curcumin-decorated nanoliposomes with very high affinity for amyloid beta1-42 peptide. Biomaterials 2011, 32, 1635-1645. [CrossRef] [PubMed]

100. Airoldi, C.; Zona, C.; Sironi, E.; Colombo, L.; Messa, M.; Aurilia, D.; Gregori, M.; Masserini, M.; Salmona, M.; Nicotra, F.; et al. Curcumin derivatives as new ligands of Apeptides. J. Biotechnol. 2011, 156, 317-324. [CrossRef] [PubMed]

101. Conti, E.; Gregori, M.; Radice, I.; Da Re, F.; Grana, D.; Re, F.; Salvati, E.; Masserini, M.; Ferrarese, C.; Zoia, C.P.; et al. Multifunctional liposomes interact with Abeta in human biological fluids: Therapeutic implications for Alzheimer's disease. Neurochem. Int. 2017, 108, 60-65. [CrossRef] [PubMed]

102. Kuo, Y.C.; Lin, C.Y.; Li, J.S.; Lou, Y.I. Wheat germ agglutinin-conjugated liposomes incorporated with cardiolipin to improve neuronal survival in Alzheimer's disease treatment. Int. J. Nanomed. 2017, 12, 1757-1774. [CrossRef] [PubMed]

103. Kuo, Y.C.; Lin, C.C. Rescuing apoptotic neurons in Alzheimer's disease using wheat germ agglutininconjugated and cardiolipin-conjugated liposomes with encapsulated nerve growth factor and curcumin. Int. J. Nanomed. 2015, 10, 2653-2672. [CrossRef] [PubMed]

104. Valldeperas, M.; Wiśniewska, M.; Ram-On, M.; Kesselman, E.; Danino, D.; Nylander, T.; Barauskas, J. Sponge phases and nanoparticle dispersions in aqueous mixtures of mono- and diglycerides. Langmuir 2016, 32, 8650-8659. [CrossRef] [PubMed]

105. Milak, S.; Zimmer, A. Glycerol monooleate liquid crystalline phases used in drug delivery systems. Int. J. Pharm. 2015, 478, 569-587. [CrossRef] [PubMed]

106. Angelova, A.; Angelov, B.; Mutafchieva, R.; Lesieur, S.; Couvreur, P. Self-assembled multicompartment liquid crystalline lipid carriers for protein, peptide, and nucleic acid drug delivery. Acc. Chem. Res. 2011, 44, 147-156. [CrossRef] [PubMed]

107. Angelov, B.; Angelova, A.; Filippov, S.K.; Drechsler, M.; Štěpánek, P.; Lesieur, S. Multicompartment lipid cubic nanoparticles with high protein upload: Millisecond dynamics of formation. ACS Nano 2014, 8 , 5216-5226. [CrossRef] [PubMed]

108. Zerkoune, L.; Lesieur, S.; Putaux, J.L.; Choisnard, L.; Gèze, A.; Wouessidjewe, D.; Angelov, B.; Vebert-Nardin, C.; Doutch, J.; Angelova, A. Mesoporous self-assembled nanoparticles of biotransesterified cyclodextrins and nonlamellar lipids as carriers of water-insoluble substances. Soft Matter 2016, 12, 7539-7550. [CrossRef] [PubMed]

109. Han, S.; Shen, J.Q.; Gan, Y.; Geng, H.M.; Zhang, X.X.; Zhu, C.L.; Gan, L. Novel vehicle based on cubosomes for ophthalmic delivery of flurbiprofen with low irritancy and high bioavailability. Acta Pharmacol. Sin. 2010, 31, 990-998. [CrossRef] [PubMed] 
110. Zou, A.; Li, Y.; Chen, Y.; Angelova, A.; Garamus, V.M.; Li, N.; Drechsler, M.; Angelov, B.; Gong, Y. Self-assembled stable sponge type nanocarries for Brucea javanica oil delivery. Colloids Surf. B 2017, 153, 310-319. [CrossRef] [PubMed]

111. Azhari, H.; Strauss, M.; Hook, S.; Boyd, B.J.; Rizwan, S.B. Stabilising cubosomes with tween 80 as a step towards targeting lipid nanocarriers to the blood-brain barrier. Eur. J. Pharm. Biopharm. 2016, 104, 148-155. [CrossRef] [PubMed]

112. Wu, H.; Li, J.; Zhang, Q.; Yan, X.; Guo, L.; Gao, X.; Qiu, M.; Jiang, X.; Lai, R.; Chen, H. A novel small odorranalectin-bearing cubosomes: Preparation, brain delivery and pharmacodynamic study on amyloid-b25-35-treated rats following intranasal administration. Eur. J. Pharm. Biopharm. 2012, 80, 368-378. [CrossRef] [PubMed]

113. Baskaran, R.; Madheswaran, T.; Sundaramoorthy, P.; Kim, H.M.; Yoo, B.K. Entrapment of curcumin into monoolein-based liquid crystalline nanoparticle dispersion for enhancement of stability and anticancer activity. Int. J. Nanomed. 2014, 9, 3119-3130.

114. Wei, L.; Li, X.; Guo, F.; Liu, X.; Wang, Z. Structural properties, in vitro release and radical scavenging activity of lecithin based curcumin-encapsulated inverse hexagonal (HII) liquid crystals. Colloids Surf. A 2018, 539, 124-131. [CrossRef]

115. Angelova, A.; Angelov, B. Dual and multi-drug delivery nanoparticles towards neuronal survival and synaptic repair. Neural. Regen. Res. 2017, 12, 886-889. [CrossRef] [PubMed]

116. Angelova, A.; Drechsler, M.; Garamus, V.M.; Angelov, B. Liquid crystalline nanostructures as pegylated reservoirs of omega-3 polyunsaturated fatty acids: Structural insights toward delivery formulations against neurodegenerative disorders. ACS Omega 2018, 3, 3235-3247. [CrossRef] [PubMed]

117. Sandhir, R.; Yadav, A.; Mehrotra, A.; Sunkaria, A.; Singh, A.; Sharma, S. Curcumin nanoparticles attenuate neurochemical and neurobehavioral deficits in experimental model of Huntington's disease. Neuromol. Med. 2014, 16, 106-118. [CrossRef] [PubMed]

118. Guerzoni, L.P.; Nicolas, V.; Angelova, A. In vitro modulation of TrkB receptor signaling upon sequential delivery of curcumin-DHA loaded carriers towards promoting neuronal survival. Pharm. Res. 2017, 34, 492-505. [CrossRef] [PubMed]

119. Chen, Y.; Angelova, A.; Angelov, B.; Drechsler, M.; Garamus, V.M.; Willumeit-Römere, R.; Zou, A. Sterically stabilized spongosomes for multi-drug delivery of anticancer nanomedicines. J. Mater. Chem. B 2015, 3, 7734-7744. [CrossRef]

120. Biswas, A.; Kurkute, P.; Jana, B.; Laskar, A.; Ghosh, S. An amyloid inhibitor octapeptide forms amyloid type fibrous aggregates and affects microtubule motility. Chem. Commun. 2014, 50, 2604-2607. [CrossRef] [PubMed]

121. Adak, A.; Das, G.; Barman, S.; Mohapatra, S.; Bhunia, D.; Jana, B.; Ghosh, S. Biodegradable neuro-compatible peptide hydrogel promotes neurite outgrowth, shows significant neuroprotection, and delivers anti-Alzheimer drug. ACS Appl. Mater. Interfaces 2017, 9, 5067-5076. [CrossRef] [PubMed]

122. Shrestha, H.; Bala, R.; Arora, S. Lipid-based drug delivery systems. J. Pharm. 2014, 2014, 1-10. [CrossRef] [PubMed]

123. Ganem-Quintanar, A.; Quintanar-Guerrero, D.; Buri, P. Monoolein: A review of the pharmaceutical applications. Drug Dev. Ind. Pharm. 2000, 26, 809-820. [CrossRef] [PubMed]

124. Bousquet, M.; Saint-Pierre, M.; Julien, C.; Salem, N.; Cicchetti, F.; Calon, F. Beneficial effects of dietary omega-3 polyunsaturated fatty acid on toxin-induced neuronal degeneration in an animal model of Parkinson's disease. FASEB J. 2008, 22, 1213-1225. [CrossRef] [PubMed]

(C) 2018 by the authors. Licensee MDPI, Basel, Switzerland. This article is an open access article distributed under the terms and conditions of the Creative Commons Attribution (CC BY) license (http:/ / creativecommons.org/licenses/by/4.0/). 